\title{
Pałac w Wilanowie - królewska ,villa rustica”, jako ośrodek dóbr ziemskich i czynnik wpływający na kształt rozwoju jednej z dzielnic Warszawy
}

\author{
Katarzyna Dankiewicz
}

\begin{abstract}
Zaktad Dziedzictwa Architektonicznego i Sztuki, Wydziat Architektury, Politechnika Warszawska, e-mail:kadan@wp.eu
\end{abstract}

Streszczenie: Barokowa willa królewska w Wilanowie oddalona od głównej siedziby Jana III Sobieskiego - zamku królewskiego w Warszawie, była w 4 ćw. XVII wieku luksusowym miejscem letniego wypoczynku, jednocześnie funkcjonowała jako samowystarczalna rezydencja wiejska otoczona folwarkami i współpracującymi z nią ośrodkami w dobrach wilanowskich króla. Począwszy od 1677 roku król Jan III, a po nim kolejni właściciele magnaci z rodów: Sieniawskich, Czartoryskich, Lubomirskich, Potockich i jako ostatni, aż do czasów II wojny światowej - Braniccy, podporządkowywali swej podwarszawskiej siedzibie okoliczne wsie rozwijając klucz wilanowski. Konsekwentna rozbudowa, początkowo willi następnie pałacu podkreślała status społeczny, możliwości finansowe właścicieli, gust i poziom wiedzy architektonicznej projektantów oraz inwestora, zaś dołączanie kolejnych budowli reprezentacyjnych do zespołu, wytyczanie założeń parkowo-ogrodowych według najlepszych europejskich wzorów i stylów, regulacja istniejących dróg oraz budowa nowych połączeń komunikacyjnych utwierdzały w przekonaniu o wielkości właściciela. Działania na tak szeroką skalę były możliwe ponieważ tereny te stanowiły niepodzielną rozległą własność ziemską niewychodzącą z rąk jednego właściciela przez niespełna trzysta lat. Inwestycje wówczas przeprowadzone stanowią dziś o wartościach dzielnicy. Budowle wokół pałacu wilanowskiego tworzą klimat historyczny, nawiązujący do spuścizny architektonicznej z epoki baroku, klasycyzmu i historyzmu. Rozwój obszaru bliskiego pałacowi wilanowskiemu opierał się o wytyczone dawniej szlaki komunikacyjne, osie widokowe, dziś dające się odczytać. Pałac pozostaje niewątpliwie głównym węzłem tej struktury. Współczesna zabudowa dotarła już do zabytkowego centrum dzielnicy, a budowane od 2000 roku na błoniach wilanowskich nowe założenie urbanistyczne - Miasteczko Wilanów - nie tylko ożywiło ten rejon, ale i wzbudziło pytania o zachowanie genius loci. Czy dwa różne organizmy uda się połączyć i stworzyć integralną przestrzeń w rejonie pałacu i czy architektura nowa i dawna mogą być synergiczne względem siebie, okaże się po skończonej realizacji.

Słowa kluczowe: barokowa willa królewska, pałac magnacki, otwarty krajobraz, osie widokowe, genius loci, architektura dawna i nowa.

\section{Wstęp}

Walory krajobrazowe skarpy warszawskiej doceniła w połowie XVI wieku królowa Bona, budując dla siebie w Ujazdowie willę - Belweder. Kolejne podmiejskie rezydencje władców i blisko związanych z dworem magnatów Rzeczypospolitej także wznoszono w rejonie Ujazdowa, następnie Mokotowa, Kabat, zaś na niżej położonych terenach podskarpowych i nadwiślańskich urządzano ogrody i zwierzyńce, jak w XVII wieku Łazienka w Ujazdowie, 
czy wille i dwory w Czerniakowie oraz Wilanowie. Wiele dróg do dnia dzisiejszego przebiega dawnymi lub zbliżonymi traktami, ich połączenia, skrzyżowania nieprzypadkowo znajdują się w obecnym położeniu, co wykazała analiza kartograficzna planów i map XVIII-XIX wiecznych i współczesnych oraz opracowań.

\section{Wilanów a granice Warszawy}

Warszawa rozwijała się w swych granicach począwszy od średniowiecznych pierścieni murów miejskich następnie w obszarze wyznaczonym przez Wał Zygmuntowski usypany w 1621 roku i ukończony w 1624 r., który „,Z górą pół wieku” zakreślał południową granicę miasta na wąwozie ulicy Karowej, przecinającej Krakowskie Przedmieście na wysokości ulicy Ossolińskich. W XVII w. Ujazdów i ogrody podskarpowe z Łazienka projektu Tylmana z Gameren realizowaną w latach 1676-1683 dla ówczesnego właściciela tych dóbr Stanisława Herakliusza Lubomirskiego, marszałka wielkiego koronnego na dworze Jana III Sobieskiego, pozostawał terenem podmiejskim. Kolejne obwałowania stolicy z 1770 r., prowadzące drogą Polną do rogatki mokotowskiej, następnie Belwederską do kolejnej rogatki, objęły swym zasięgiem obszar Łazienek - już Stanisławowskich, dochodząc do traktu czerniakowskiego nad Wisłą. W okresie międzywojennym nastąpiła tzw. inkorporacja przedmieść [1], a opracowany w 1916 r. przez Koło Architektów plan regulacyjny dla Warszawy i okolic ${ }^{1}$, stanowił podstawę poszerzonych w 1917 r. granic miasta włączających do niego gminy Mokotów, Czyste, folwark Rakowiec oraz osady: Czerniaków i Siekierki. Wilanów rozwijał się poza miastem jako autonomiczna jednostka przestrzenna. Dopiero w 1951 roku Wilanów wraz z przynależnymi do niego wsiami, czyli z kluczem wilanowskim wszedł w granice Warszawy. Do powierzchni nowej dzielnicy miasta oraz części dzielnic Ursynowa i Mokotowa dołączono wówczas znajdujący się pomiędzy skarpą warszawską a Wisłą obszar będący w dużych fragmentach już zakomponowanym urbanistycznie, architektonicznie i krajobrazowo.

\section{Chronologia własności. Kształtowanie się ośrodka dóbr ziemskich}

\subsection{Wilanów Jana III Sobieskiego 1677-1696}

Jan III Sobieski w niedługim czasie po objęciu w 1674 r. tronu rozpoczął tworzenie zespołu rezydencjonalnego przy oficjalnej siedzibie na zamku królewskim w stolicy [2]. Ulubionym miejscem króla miała stać się willa w podwarszawskiej wsi - villa rustica, służąca odpoczynkowi i reprezentacji. Król nie przypadkowo chyba wybrał Wilanów, położony w sąsiedztwie dóbr czerniakowskich i ujazdowskich marszałka

Historia Wilanowa (Milanowa) sięgała wczesnego średniowiecza kiedy to stanowił on centrum włości należących do opactwa benedyktynów płockich, którzy wznieśli tu prawdopodobnie w XII w. pierwszy kościół. Zasięg parafii [3, 4, 5] obejmował wówczas wsie: Milanowo oraz Tarnowo, później Czarnowo w dobrach czerniakowskich (dzisiejsze Siekierki), Służew, Powsin, a także tereny Zarzna ( dziś Zerzeń) leżące po przeciwnej stronie Wisły (związane $\mathrm{z}$ istniejącą tu przeprawą ${ }^{2}$. Milanowo ${ }^{3}$ położone było przy ważnym trakcie

\footnotetext{
1 Pełna nazwa zespołu tworzącego Plan Wielkiej Warszawy to: Koło Architektów przy Stowarzyszeniu Techników Polskich wraz z Zarządem Miasta jako organem wykonawczym Magistratu m.st. Warszawy.

2 Potwierdza tę przeprawę Plan Deutcha z 1777 r. z archiwum AGAD, na którym oznaczona jest ona w poprzek Wisły linią przerywaną i napisem przewóz pomiędzy Siekierkami a Zbytkami, leżącymi również dziś tuż obok Zerzenia.

3 w skład kompleksu milanowskiego wchodziły trzy wsie, z czasem wchłonięte przez Wilanów: Milanów, Kępa i Błonie.
} 
Zakroczym - Czersk. Tutaj przecinało się z nim połączenie idące w kierunku zachodnim do Służewa, położonego na krawędzi skarpy, w miejscu strategicznym o cechach obronnych ale i o walorach widokowych, zasobnego w pola uprawne. Do 3 ćwierci XVII wieku Wilanów nosił nazwę Milanowo od nazwiska szlacheckiego rodu Milanowskich, którzy otrzymali te tereny z nadania książęcego, a ich położenie przy trakcie czerskim wiodącym było dogodne w drodze z grodu jazdowskiego i późniejszej Warszawy. Wcześniej były tu dobra duchowne, ośrodek parafii, której zasięg obejmował Milanowo z przyległymi nadrzecznymi osadami.

W Wilanowie znajdował się już we wczesnym średniowieczu istotny węzeł komunikacyjny łączący tę wieś z położonym na szczycie skarpy Służewem - od 1238 roku ośrodkiem sąsiedniej parafii, skąd prowadziła, wzdłuż krawędzi skarpy warszawskiej, droga lubelska do Warszawy. Ze Służewa spływał ponadto wartkim strumieniem potok służewiecki mający swe ujście do jeziora wilanowskiego, znajdowały się tu także młyn i stawy rybne.

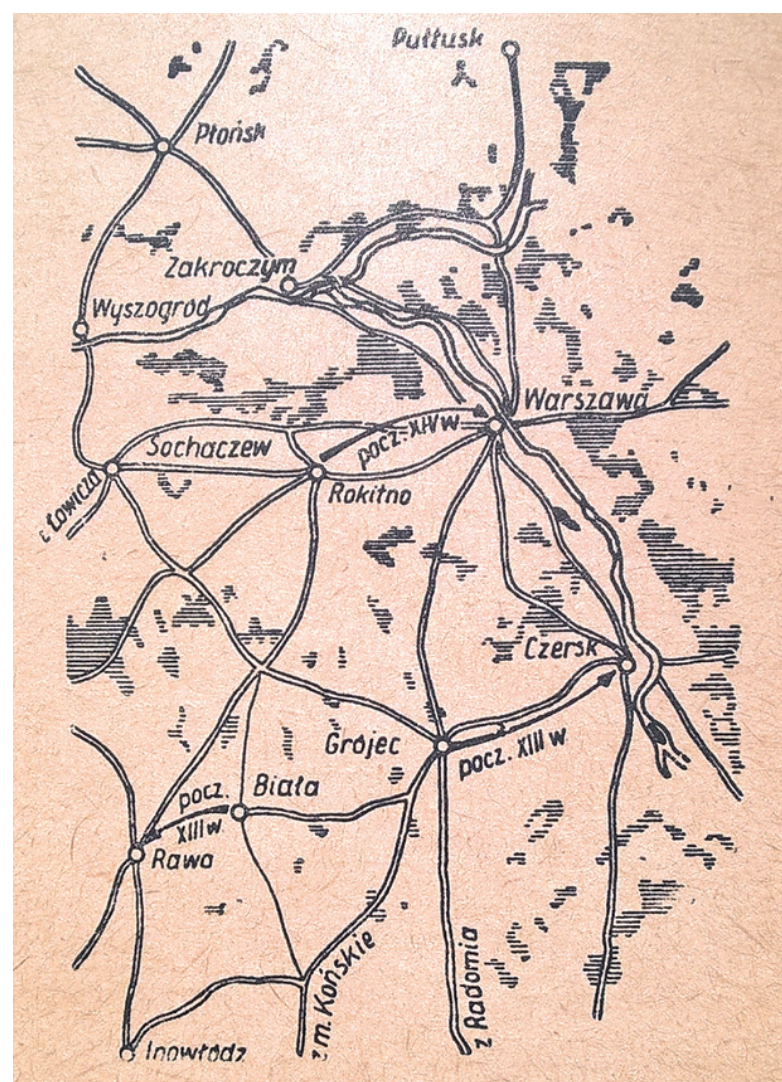

Il. 1. Układ sieci drogowej na Mazowszu (rysunek według opracowania A. Gieysztora), za: Szwankowski E., Warszawa, Warszawa 1952, s. 12

Milanowo położone było w otoczeniu zieleni pól, łąk i lasów, a w połowie XVII wieku stanowiło najdalej wysuniętą na południe od Warszawy rezydencję podmiejską, początkowo magnacką - Jakuba Rozrażewskiego, później Bogusława Leszczyńskiego i wreszcie Stanisława Krzyckiego, następnie od 1677 roku już jako villa nova - Wilanów, znacznie rozbudowany - rezydencję królewską Jana III Sobieskiego [6, 7]. Położenie na tarasie niższym pradoliny 
Wisły zapewniało bliskość rzeki, potoków i strumieni, licznych stawów i jezior, rozległych łąk i lasów łęgowych, które to warunki sprzyjały zarówno obronności jak i rekreacji, rzeką zaś transportowano towary. Pola i łąki wilanowskie rozciągały się naprzeciw rezydencji - od głównego traktu czerskiego aż do podnóża wzgórza służewskiego.

W latach 1677-16824 w Wilanowie Augustyn Locci młodszy5 realizując zamierzenia królewskie wzniósł dla Jana III Sobieskiego rezydencję w stylu włoskiej willi, nazwanej Villa Nova, w latach 1688-94 rozbudowaną. Willa uzyskała wówczas ostateczną zmonumentalizowaną formę pałacu o cechach włoskiego baroku, poprzez środkową nadbudowę piętra mieszczącego salę uczt, w wielkiej sieni zaś, naprzeciw wejścia głównego stanął posąg konny króla [8]. Całość prezentowała się jako osiowe zalożenie pałacowo-ogrodowe z centralnie umieszczonym pałacem - dominantą, który zgodnie z zasadami kompozycji barokowej poprzedzony był dwoma dziedzińcami, z ozdobną kamienną bramą na osi ogrodzenia, od której odchodziła prostopadle do traktu czerniakowskiego aleja dojazdowa, wydłużona dalej, za traktem czerskim, wytyczonym prostym kanałem nawadnianym przez potok służewiecki spływający ze skarpy. Za pałacem główną oś wyznaczał parterowy ogród tarasowy, z którego paradnymi schodami dochodziło się do tarasu dolnego z symetrycznie położonymi dwoma sadzawkami, między którymi dalej wzdłuż strzyżonych boskietów aleja prowadziła do jeziora wilanowskiego, skąd groblą i mostkiem docierało się na teren nadrzecznych łąk. Oś królewska z kanałem zaznaczona została wyraźnie przez ocembrowanie, zaś w dalekim krajobrazie poprzez zaakcentowanie jej zespołem pasieki położonej około pięćset metrów za kanałem, w kierunku zachodnim. Pasieka - zespół składający się z budynku (lub dwóch) ustawionych w kształcie litery L, obsadzony wokoło drzewami, zapewne obficie kwitnącymi, otoczona była czworokątnym ogrodzeniem. Ukazuje ją najwcześniej plan saski dóbr wilanowskich z ok. 1732 r. (il. 2) publikowany przez Wojciecha Fijałkowskiego [9], a plan dóbr Wilanowa z 1747 r. (il. 4) znajdujący się w zbiorach AGAD, opisuje literą „,P”, zaś w legendzie u dołu mapy pismem ozdobnym: ,Zirfnen (Bienen?) Garten”. Pasieka omawiana jest też w korespondencji Locciego z królem z dnia 26 IX 1681 roku: „Pasiekę każe obsadzić drzewkami y drogi których tam mało, pozatracać", a także w korespondencji Elżbiety Sieniawskiej, kolejnej właścicielki Wilanowa, która remontowała ,zrujnowaną” wówczas w 1722 r. pasiekę wilanowską i zleciła w niej „powiększyć ilość pni” [10, 11].

Kierunek głównej osi kompozycyjnej, być może już wówczas obsadzonej z obu stron drzewami, mógł naprowadzać na tzw. Lodownię urządzoną w zboczu wzgórza służewskiego. Miejsce służyć miało do przechowywania lodu wyjętego zimą z przerębla rzeki, aby w okresie letnim można było w nim chłodzić produkty spożywcze chroniąc je przed zepsuciem, zgodnie z listem Locciego, który uzgadniając wszystkie poczynania budowlane w Wilanowie ze swoim mocodawcą pisał więc do króla dnia 12 IX 1681 r.: „na lodownio i fons należna będo sposobne mieisca pod Guro Stużewską, która w sobie niemal wszystka glinę ma, a te miejsca sa ad septentrionem”. O istnieniu ziemianki i jamy czytamy u Marty Piber w monografii Służewa

\footnotetext{
4 O historii budowy pałacu wilanowskiego, jego architekturze oraz wystroju rzeźbiarskim, wnętrzach powstało wiele istotnych publikacji znanych badaczy, m. in.: Wojciechowski J., Pałac wilanowski $i$ jego obecna restauracja, „Architektura i Budownictwo” 1928, T. IV, z. 3; Scholze H. E., Pałac w Wilanowie, Kwartalnik Architektury i Urbanistyki, R. IV, 1959, z. 3-4; W. Fijałkowski, Wilanów, Warszawa 1973; Miłobędzki A., Jan III $i$ Wilanów, w: Sztuka Warszawy, Warszawa 1986, s. 109-112; Cydzik J., Fijałkowski W., Wilanów - dzieje, architektura, konserwacja, Warszawa 1989; Fijałkowski, Królewski Wilanów, [bm., bd.]; Karpowicz M., Sekretne treści warszawskich zabytków, Warszawa 1981; Karpowicz M., Co nam mają do powiedzenia fasady Wilanowa, Warszawa 2011. Duży wybór publikacji wydaje ośrodek badawczy Muzeum Pałacu w Wilanowie.

5 Augustyn Locci mł. (1640-1730) - polak włoskiego pochodzenia, studiował architekturę w Rzymie, był synem nadwornego architekta Wazów, również Augustyna Locci. Prowadził on prace projektowe i budowlane w Wilanowie dla króla Jana III.
} 
[3 - s. 35], opisującej wykopaliska, których tu dokonano w latach 70-tych XX wieku podczas prac archeologicznych: „w wykopie na wschodnim zboczu, w pobliżu zakrystii kościoła, natrafiono na ziemiankę oraz jamę. (...) Jama znajdowała się na południe od ziemianki"6. Ta lub podobna zacieniona ziemianka była zapewne przedmiotem rozważań Locciego w liście do króla o jej wybudowaniu lub zagospodarowaniu już istniejącej.

Analogicznie wydłużona została oś kompozycyjna w przeciwnym kierunku, z pałacu przez ogrody tarasowe szeroką aleją, którą za jeziorem Wilanowskim przechodziło się w szeroką przecinkę i dalej duktem leśnym trafiało wprost do gospodarstwa rybnego nad brzegiem Starej Wisły - Wilanówki, skąd rozciągał się widok łąk nadwiślańskich i folwarku w Zawadach, co dobrze obrazuje wspomniany plan saski z ok. 1732 r., na którym przy zabudowaniach nad rzeczką czytamy: „Fischer R...”, a na późniejszym nieco planie dóbr z 1747 r. potwierdza się jego położenie. Mapa klucza wilanowskiego ze zbiorów AGAD z 1807 r. dokumentuje z kolei zabudowania folwarku w Zawadach, na zamknięciu osiowej drogi z pałacu. Nie można wykluczyć istnienia takich akcentów w przestrzeni w czasach Sobieskiego, wszak Zawady należały do króla, a istniejące od dawna zabudowania wiejskie, folwark, przeprawa rzeczna, sugerują również rybołówstwo, pośród innych zajęć miejscowej ludności, zaopatrującej zapewne stół królewski w rozmaite produkty lokalne.

Augustyn Locci kierował równocześnie robotami ziemnymi przy zakładaniu ogrodu i zajmował koordynacją niezwykle ważnych dla wznoszonej willi z ogrodem, prac hydrotechnicznych, związanych z doprowadzaniem wody z okolicznych źródeł i potoków do stawów i sadzawek w ogrodzie, budową tam i przepustów, grobli i mostków - o czym informował sukcesywnie o postępie robót w korespondencji do króla. Aby móc objąć pracami melioracyjnymi stawy i jeziorka służewskie, regulację potoku służewieckiego i dopływów Wilanówki, Jeziora Wilanowskiego król zdecydował się w latach 1684-93 dokupić kolejne sąsiednie wsie położone na niższym tarasie: Zawady, Powsinek, część Powsina Wielkiego (Łazy, Lisy, Kempa, Kierszek) z terenami łąk i strumieni nad Wilanówką, oraz wyżej położone części w Wolicy pod skarpą i Służew (bez części kościelnych), na których znajdowały się, prócz pól uprawnych, źródła, stawy oraz potok służewiecki zasilający kanał na osi pałacu i jezioro w Wilanowie. Dokupione tereny były źródłem rozmaitych płodów rolnych m.in. zboża, siana, hodowano tu bydło, ryby (staw wilanowski i plebański w Służewie, jezioro, rzeka), konie (dla których wzniesiono stajnie królewskie w Wilanowie). Ponadto browary w Wolicy i Wilanowie, karczmy w Wilanowie, Powsinie, Służewie i być może w Zawadach, także wiatraki - w Wilanowie i Służewie, były źródłem dochodu oraz produktów spożywczych. Ogrody użytkowe przy pałacu dostarczały owoców i warzyw na stół królewski.

Jan III Sobieski w latach 1677-1696 zgromadził w dobrach wilanowskich w całości lub w części klucz 12 wsi, w których znalazło się: pięć folwarków, sześć dworów, port w Wilanowie, dwa browary, cztery karczmy, dwa wiatraki Pałac w Wilanowie stał się jednocześnie miejscem letniego wypoczynku i centrum dóbr ziemskich, podporządkowując swojej pozycji ośrodki w sąsiednich wsiach, które spełniały wobec niego funkcje gospodarcze. Ze względu na walory położenia i bliskość stolicy, uzupełniał on zespół rezydencjonalny w mieście i na przedmieściu ( zamek królewski w Warszawie, willa królewska na przedmieściu - Villa Regia, późniejszy Pałac Kazimierzowski) o funkcję rekreacyjną, a także reprezentacyjną, jako rezydencja podmiejska wyróżniająca się formą czytelną w krajobrazie.

\footnotetext{
6 Przypuszcza się, że jama była współczesna ziemiance i być może służyła jej jako spiżarnia. Znalezione fragmenty naczyń ceramicznych pochodziły z VI - XVI w.

7 Autorka niniejszego artykułu prowadziła badania kartograficzne dotyczące dóbr wilanowskich, zakończone wnioskami; za: Katarzyna Dankiewicz, Przemiany w obszarze dóbr wilanowskich od połowy XVII do połowy XVIII w., praca doktorska - maszynopis, Wydział Architektury Politechniki Warszawskiej, 2005, s. 94-96.
} 


\subsection{Wilanów Elżbiety Sieniawskiej 1720-1729}

Elżbieta Sieniawska [12] była blisko związana z domem Sobieskich w związku z pełnieniem przez swego ojca Stanisława Herakliusza Lubomirskiego wysokiego stanowiska państwowego u boku króla, ponadto królowa Kazimiera Sobieska darzyła ją wielkim zaufaniem ${ }^{8}$. Sieniawska żywo interesowała się losami spuścizny po królu Janie i gdy tylko nadarzyła się okazja dysponując niemałym własnym majątkiem, także otrzymanym w spadku po zmarłym w $1702 \mathrm{r}$. ojcu, chętnie odkupiła posiadłość w Wilanowie. Będąc bardzo przedsiębiorczą hetmanową zajęła się tworzeniem dla obojga małżonków podmiejskiego zaplecza gospodarczego i miejsca do mieszkania i wypoczynku pod miastem, jako uzupełnienia dla stołecznego pałacu, który posiadali na Krakowskim Przedmieściu. Nabyła więc w 1720 r. od królewicza Konstantego Sobieskiego dobra wilanowskie $[13,14]$ z pałacem, rozpoczynając intensywne prace remontowe zaniedbanych wieloletnią dzierżawą folwarków, dworów i starając się zachować nienaruszony charakter rezydencji królewskiej ${ }^{9}$ Elżbieta Sieniawska jednocześnie podjęła rozbudowę pałacu o mieszkalne skrzydła boczne dla siebie, które ujmowały dziedziniec honorowy po bokach, realizując być może wcześniejsze zamierzenia króla [15]. Skrzydło północne przeznaczone dla hetmanowej i jej męża ukończono do śmierci Sieniawskiej, zaś południowe przeznaczone zapewne dla córki Marii Zofii, zostało nie wykończone wewnątrz [16]. Sieniawska w latach 1720-27 dość szybko uzupełniła brakujące części we wsiach kupionych wcześniej przez króla Sobieskiego, a także powiększając dobra o nowe sąsiednie wsie. Zgromadziła ostatecznie w kluczu wilanowskim 15 całych wsi: Wilanów (z Kępą i Błoniem), Powsinek, Powsin, Zawady, Lisy, Łazy, Narty, Kempę (Powsińską - obok Okrzeszyna ${ }^{10}$ ), Służew, Wolicę, Kabaty, Moczydło, w których było: 8 folwarków i dworów, port rzeczny w Wilanowie, 3 browary, 5 karczem, 2 wiatraki, pasieka, oraz cegielnia w Kabatach. Sieniawska nabyła ponadto przy udziale męża 6 wsi w kluczu żabienieckim, z Żabieńcem i Chojnowem, Jesówką, Warchołami, Jastrzębiem, Ossowem koło Piaseczna, oraz 7 wsi w kluczu zastowskim, z Zastowem, częścią Zerzenia, i nowymi wsiami Koło, Las, Zbytki, Olendry, Łąki, na prawym brzegu Wisły, a także kompleks leśny w kluczu nieporęckim z wsiami: Nieporęt, Katy Węgierskie, Rembielszczyzna, Kobiałka, Kąty Grodziskie, Białobrzegi, Pustelnik [7 - s. 292-300, 307-310], [17] komasując obszar dużo większy niż króla Jana III - zaplecze gospodarcze dla pałacu na przedmieściu w Warszawie i rozbudowywanego pałacu w Wilanowie. Ustalony wówczas zasięg i granice dóbr pozostawały niezmienne do 1807 r., co potwierdziła kwerenda map i planów dóbr ze zbiorów AGAD.

Wzbogacił się także repertuar form stosowanych w celach wizerunkowych przez nowego właściciela - aleja z osiowym kanałem królewskim akcentowanym na polach wilanowskich zespołem pasieki (wyremontowanej w 1722 r.) teraz wyraźnie przedłużona została daleko wybiegającą osią widokową, obsadzoną z obu stron drzewami, sięgającą lesistego wzgórza służewskiego (w miejscu królewskiej lodowni u podnóża?). Powiązanie przestrzenne pałacu w Wilanowie ze Służewem na skarpie z pewnością miało znaczenie symboliczne podkreślające zasięg dóbr oraz pozycję społeczną właściciela ${ }^{11}$.

\footnotetext{
8 Elżbieta Sieniawska (1669-1729) - córka S.H. Lubomirskiego marszałka wielkiego koronnego za Jana III Sobieskiego. Żona Adama Mikołaja Sieniawskiego, hetmana wielkiego koronnego za Augusta II, kasztelana krakowskiego. Kontynuowała ona po śmierci Jana III Sobieskiego od 1723 r. rozbudowę w Wilanowie, jako kolejna właścicielka, kontaktując się z A. Loccim w sprawach dotyczących pałacu. Patrz: List Locciego do E. Sieniawskiej z 3 III 1725 r.

9 Korpus główny pałacu E. Sieniawska traktowała jak część muzealną po królu Janie III Sobieskim, nie wprowadzając tam żadnych zmian.

${ }^{10}$ K. Dankiewicz, op. cit., ryc. 25 - identyfikacja lokalizacji wsi na Kępie Zawadowskiej.

${ }^{11}$ Nieprzypadkowo w miejscu zakończenia na skarpie wspomnianej osi, jakby ją dalej akcentując, powstanie w 1776 r. willa Rozkosz wnuczki hetmanowej Sieniawskiej - Izabeli z Czartoryskich Lubomirskiej, późniejszy pałacyk w Ursynowie.
} 
Dzięki działaniom komasacyjnym można było realizować swobodnie przedsięwzięcia inwestycyjne nie tylko w samym Wilanowie, ale i w Kabatach gdzie Elżbieta Sieniawska wybudowała w 1726 r. nowy dwór i utworzyła Bażantarnię służącą jej ulubionym polowaniom, dołączając w ten sposób do swego zespołu rezydencjonalnego przy stolicy, element uzupełniający służący rekreacji i rozrywce. Było to wielkoprzestrzenne założenie osiowe z wachlarzem sześciu promienistych alei widokowych rozmieszczonych symetryczne po bokach środkowej - siódmej alei, wyciętych w lesie, poniżej krawędzi skarpy. Oś główną akcentowały murowane kordegardy prowadzące do lasu ogrodzonego z czterech stron: pod skarpą, na terenie Powsinka i na skarpie - już obrębie wsi Kabaty, tam także oś główna dochodziła aleją do drugiej kordegardy. U podnóża skarpy, poniżej lasu po bokach osi znalazły się dwa drewniane budynki myśliwskie, widoczne na planie dóbr z 1747 r. (por. il. 3 ) i na mapie dóbr z ok. 1784 r. (oba plany ze zbiorów AGAD), opisane jako ,pomieszkanie strzeleckie”.


Il. 2. Fragment Planu dóbr królewskich w Wilanowie z ok. 1732. Landesamt für Denkmalpflege Dresden, wg: W. Fijałkowski, Królewskie założenia ogrodowe w poludniowej Warszawie, w: Królewskie ogrody w Polsce, pod. red. M. Szafrańskiej, Warszawa 2001, s. 205

Il. 3. Fragment schematu ukształtowania przestrzennego klucza wilanowskiego - rekonstrukcja stanu w 1729 r. - opracowała autorka, na podstawie: Planu saskiego dóbr królewskich z ok. 1732 r. publikowany przez W. Fijałkowskiego oraz Mappa Powsinka i Wilanowa wg de Pircha, 1747 r., ze zbiorów AGAD oraz Mapa dóbr klucza wilanowskiego, 1807 r. - ze zbiorów AGAD.

Legenda: 1 - pasieka na osi głównej założenia, 2 - gospodarstwo rybne nad Wilanówką, 3 - osiowa aleja w Bażantarni, 4 - folwark w Zawadach

Bażantarnia podkreślała zalety krajobrazowe: dalekich perspektyw osiąganych dzięki uformowaniu promienistych osi widokowych i centralnego, półkolistego placu położonego na skarpie w miejscu widokowym na dalekie łąki nadwiślańskie i nurt rzeki. Choć najwcześniej została udokumentowana na wspominanym już planie saskim dóbr z ok. 1732 r., to nie wydaje się możliwe, by król August II mógł ją utworzyć, mając w ciągu trzech lat (1730-33) 
w dzierżawie Wilanów i Powsinek z Bażantarnią ${ }^{12}$. Realizował on w tym czasie, wzorując się być może na koncepcji Sieniawskiej, kompozycję o układzie wachlarzowych alejek w zwierzyńcu ujazdowskim, dzierżawionym od Lubomirskich.

Sieniawska była także fundatorką kościoła wybudowanego w latach 1726-28 w Powsinie. Umierając w 1729 r. pozostawiła swej córce Zofii Marii imponujące latyfundium na Mazowszu.

\subsection{Czartoryscy i Lubomirscy w Wilanowie 1730-1799}

Zofia Maria z Sieniawskich wniosła w 1731 r. w wianie do małżeństwa z księciem Augustem Czartoryskim całe dobra wilanowskie, które niedługo potem dzięki sprawnemu gospodarowaniu doprowadzone zostało do jeszcze większej świetności. Pierwszą ważną inwestycją Augusta Czartoryskiego w dobrach wilanowskich była odbudowa w 1742 r. kościoła w Służewie „grożącego zawaleniem”, a także wzbogacona oprawa rzeźbiarska kamiennej barokowej bramy wjazdowej do pałacu Wilanowie. We wsi wilanowskiej założono również lazaret, a w ogrodzie na północ od pałacu stanęła obszerna murowana pomarańczarnia. Na przedpolu pałacu powstał ogród kuchenny z murowaną kuchnią, dalej zaś w kierunku Powsinka, przy zakolu potoku, zespół trzech budynków: browaru, karczmy i sklepu (il. 4). Inwestycja kościelna w Służewie zapewne przyczyniła się do wzmocnienia pozycji fundatora i właściciela na omawianym terenie, a poprzez uregulowanie połączenia Wilanowa i Służewa - prostą wygodną aleją - wyraźnie ją podkreśliła. Aleja prowadząca z Wilanowa do Służewa została zadokumentowana na planie dóbr wilanowskich z 1747 r. Ukazała jej nowy prosty kształt, w porównaniu z planami wcześniejszymi z ok. 1730 r. z AGAD i planem saskim z ok. 1732 r. Książę August Czartoryski, wojewoda ruski wymieniony został przez autora planu z 1747 r. - de Pircha, jako właściciel dóbr, zatem jemu przypisać należy tę ważną inicjatywę regulacji drogi w Wilanowie.

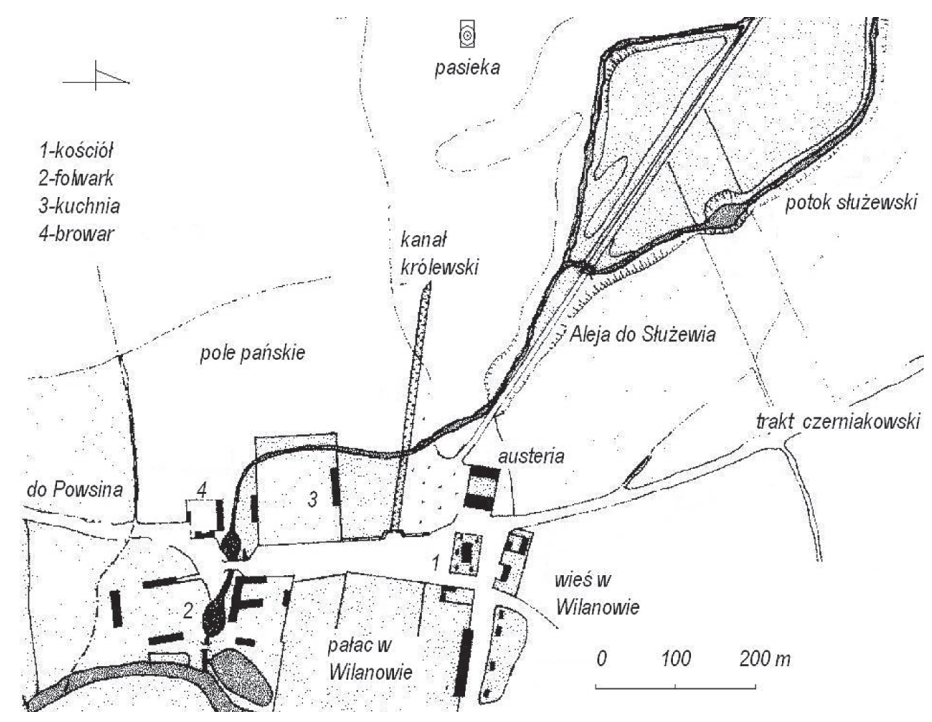

Il. 4. Fragment planu dóbr Augusta Czartoryskiego - Plan Wilanowa i Powsinka wyk. przez de Pircha, 1747 r. ze zb. AGAD - przerys wyk. Katarzyna Dankiewicz

\footnotetext{
${ }_{12}$ Miał wszak do swej dyspozycji Lasek na Kępie (Saskiej) do polowań, Marymont Sobieskich oraz Królikarnię założoną przed 1732 r. na zboczu skarpy pomiędzy Szopami a Ujazdowem, korzystał ze zwierzyńca pod zamkiem ujazdowskim tworząc w nim z podobnym co Sieniawska rozmachem układ wachlarzowy duktów leśnych.
} 
Tradycyjnie dotąd ukształtowana poprzez topografię terenu droga wiła się pod górę zakosami wzdłuż krętego potoku służewieckiego (por. il. 3 i 4), następnie skręcała wąwozem do Służewa. Nowa zaś aleja "Allee” odchodząc od traktu czerniakowskiego (czerskiego) z placu przy „austerii” wilanowskiej, miała w granicy wsi Wilanów ściśle określoną i wyznaczoną formę prostej drogi, po bokach zapewne wykończoną niskim ażurowym płotkiem, podobnie jak to ukazują osiemnastowieczne widoki Canaletta, np.: Wjazd do pałacu w Wilanowie. Służyła wygodnej komunikacji, była jednocześnie osią widokową kierującą wzrok jadącego „z góry” - na pałac wilanowski. Nowa aleja do Służewa zapoczątkowała regulację tej trasy oraz jej przedłużenie na sam szczyt w początku XIX wieku (co ostatecznie ustaliło przebieg dzisiejszej Alei Wilanowskiej).

Książę mógł podjąć niedługo potem inicjatywę dalszych prostych uregulowanych połączeń drogowych, tym razem sięgających samej Warszawy. Plan saski Ujazdowa z $1731 \mathrm{r}$. i plan z 1762 r. nasuwają takie przypuszczenie, choć niewykluczone, iż początkowo była to nie droga, a jedynie szeroki kanał - strumień doprowadzający wodę do basenu wokół Łazienki. Tereny Ujazdowa należały do dóbr Lubomirskich, a ich założyciel Stanisław Herakliusz (dziadek Zofii Czartoryskiej), mógł także zainicjować drogę w kierunku królewskiego Wilanowa, wychodzącą na wprost osiowego kanału pałacu na wodzie - Łazienki zaprojektowanej dla Lubomirskiego przez Tylmana z Gameren w latach 1676-89.

Dopiero w czasach władania Wilanowem przez Czartoryskich dodano na przedłużeniu Łazienki prosty odcinek alei obsadzonej drzewami, na co wskazuje plan Tiregaille'a z 1762 r., łączącej się z traktem wilanowskim. Plan Hennequina z 1779 r., już bez wątpliwości potwierdza prosty bieg drogi z Wilanowa (dzisiejsza al. Sobieskiego/Belwederska), z którą łączy się odcinek dojazdowy do Łazienki (już wówczas prezentują ten sam przebieg drogi wilanowskiej, jedynie widoczne są późniejsze zmiany w przebiegu odcinka odchodzącego od drogi wilanowskiej przez Łazienki Królewskie [18], przesuniętego równolegle, w stosunku do trasy zadokumentowanej w 1762 r. Nowy odcinek prowadzi już powyżej kanału królewskiego w Ujazdowie i stawu w Łazienkach i przebiega prosto u podnóża zamku tuż przy główce kanału (por. il. 5, 6, 7, 8).

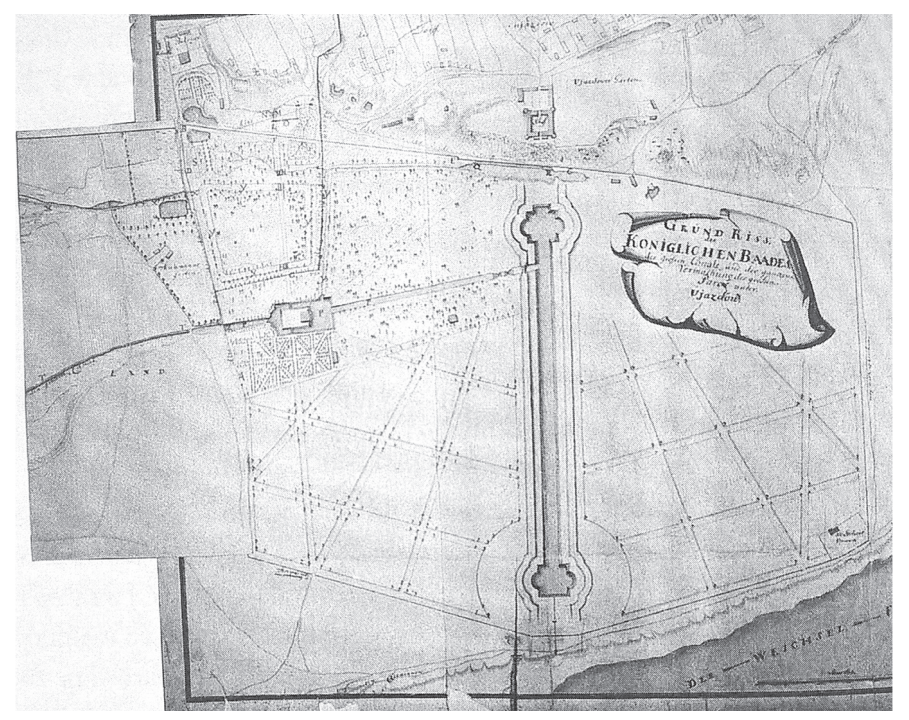

Il. 5. Ujazdów ok. 1731 ze zbiorów drezdeńskich; za: T. Bernatowiczem, za: Ogrody królewskie w Polsce, pod red. M. Szafrańskiej, Warszawa 2001, s. 268 


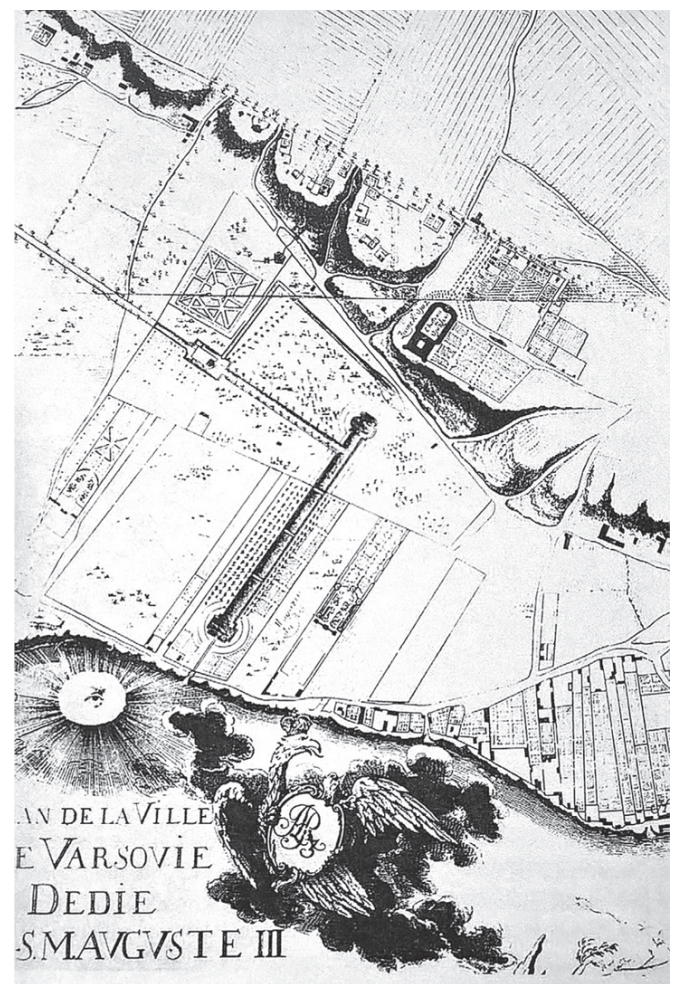

Il. 6. Ujazdów, Łazienka S. H. Lubomirskiego - fragment Planu Warszawy Tiregaille'a z 1762 r., za: E. Szwankowski, Warszawa 1952, s. 90

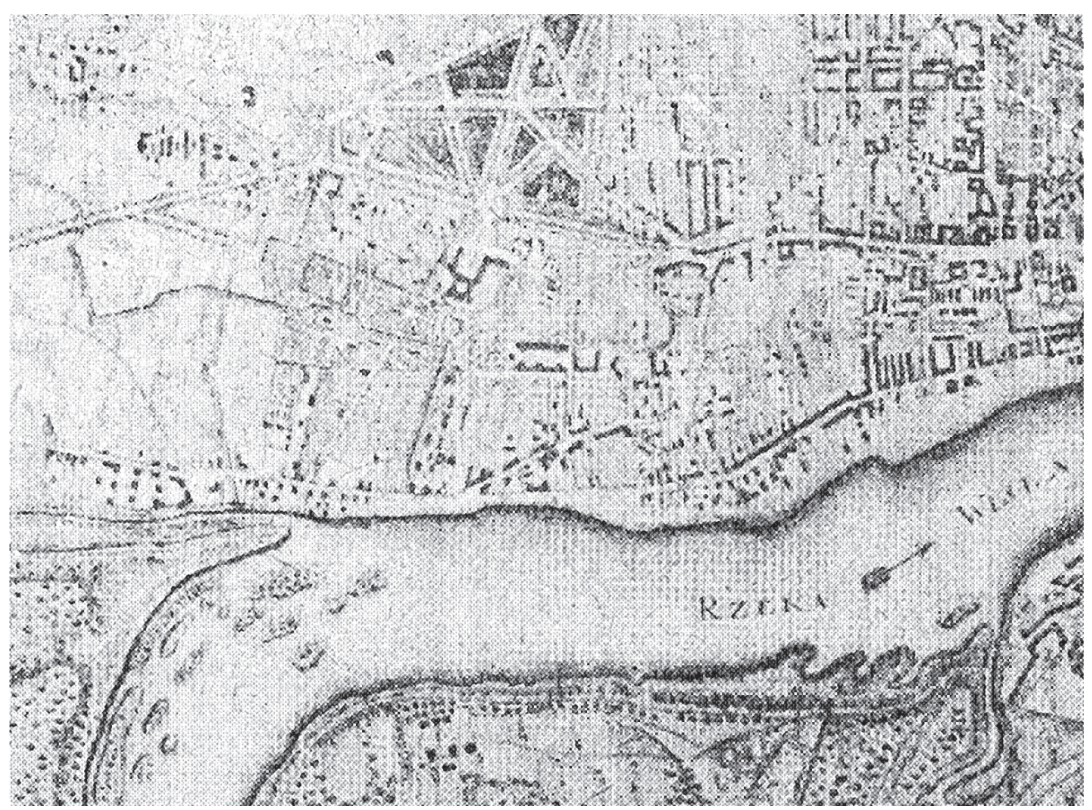

Il. 7 Plan Warszawy Hennequina 1779 r., za: E. Szwankowski, Warszawa 1952, s. 100 


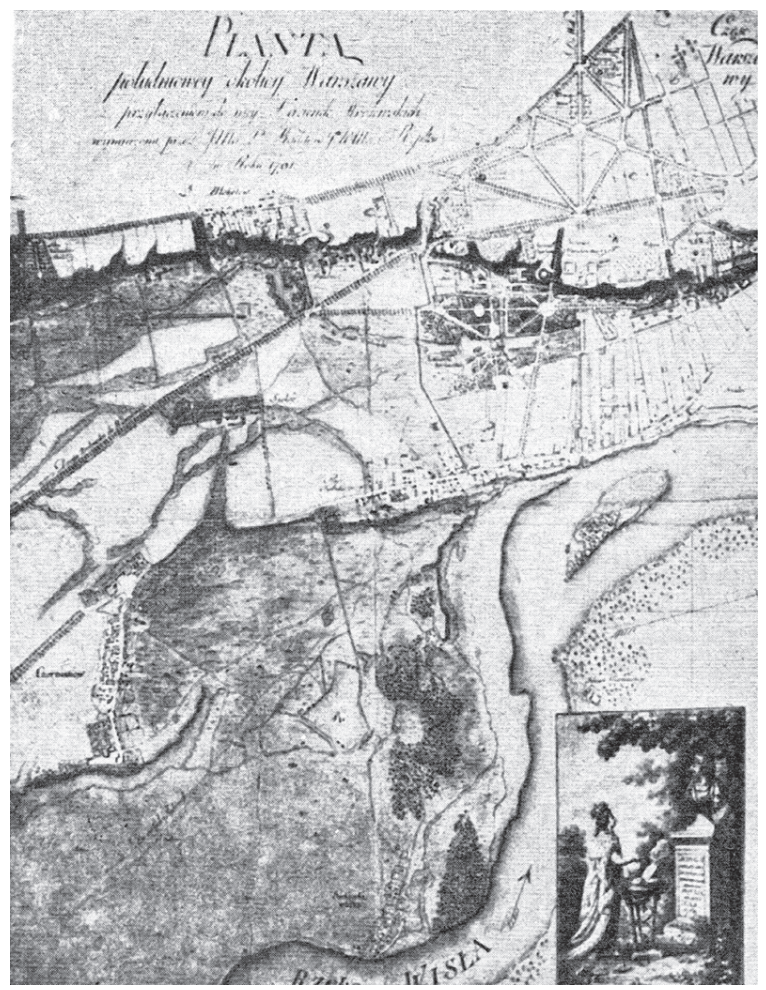

Il. 8. Plan południowej okolicy Warszawy 1791 r., za: E. Szwankowski, 1952, s. 108

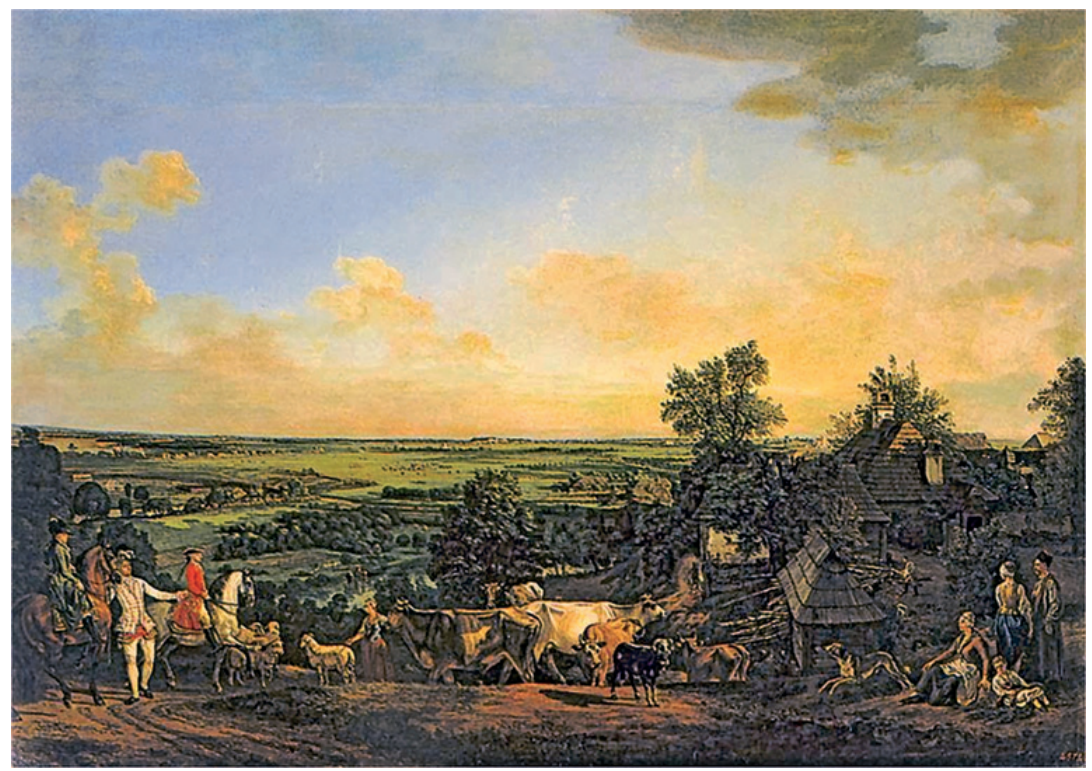

Il. 9. Bernardo Belotto zw. Canaletto, Widok łą wilanowskich, 1775; wł. Muzeum Zamku Królewskiego w Warszawie, za: https://kolekcja.zamek-krolewski.pl/obiekt/kolekcja/Malarstwo/mate$\mathrm{rial} / \mathrm{p} \% \mathrm{C} 5 \% 82 \% \mathrm{C} 3 \% \mathrm{~B} 3 \mathrm{tno} / \mathrm{id} / \mathrm{ZKW} 452$ 
Dla ambitnego i przedsiębiorczego polityka jakim był August Czartoryski, ważne stało się reprezentacyjne połączenie jego rezydencji podmiejskiej ze stolicą - było nie tylko wyrazem wielkopańskiego gestu, ale chyba głównie podkreślało pozytywne cechy jak: pomysłowość, zdolności organizacyjne, perspektywiczne myślenie, i prestiż jej inwestora. Każdemu kto podróżując tymi drogami dostrzegał widoczne przestrzenne walory i akcenty w monotonnym krajobrazie mazowieckim, wojewoda ruski August Czartoryski jawić się mógł jako znakomity gospodarz, także w oczach gości i stronników Familii (do której należał również Stanisław August Poniatowski).

Drugą inwestycją ważną wizerunkowo było ufundowanie przez księcia Augusta Czartoryskiego w 1772 roku w Wilanowie nowego kościoła murowanego (na miejscu starego drewnianego), według projektu Jana Kotelnickiego. Zapewne wybudowany został w intencji zmarłej rok wcześniej żony księcia, Zofii Marii z Sieniawskich. W latach 1775-78 z inicjatywy córki - Izabeli z Czartoryskich Lubomirskiej, dobudowano do południowego skrzydła pałacu wilanowskiego pawilon łazienki, obok stanęła oficyna kuchenna i kordegarda, według projektów Szymona Bogumiła Zuga [19]. W 1776 r. dla Izabeli i jej męża marszałka Stanisława Lubomirskiego, na szczycie wzgórza służewskiego, w lesistym terenie (na który wskazywała oś, poprowadzona z pałacu wilanowskiego za E. Sieniawskiej) zbudowano willę Rozkosz, zaś w 1780 r. według projektu Sz. B. Zuga wzniesiony został letni pawilon w Bażantarni [20]. Oba obiekty od 1785 r. użytkowane były z kolei jako podmiejskie rezydencje przez córkę Lubomirskich - Aleksandrę i jej męża Stanisława Kostkę Potockiego ${ }^{13}$.

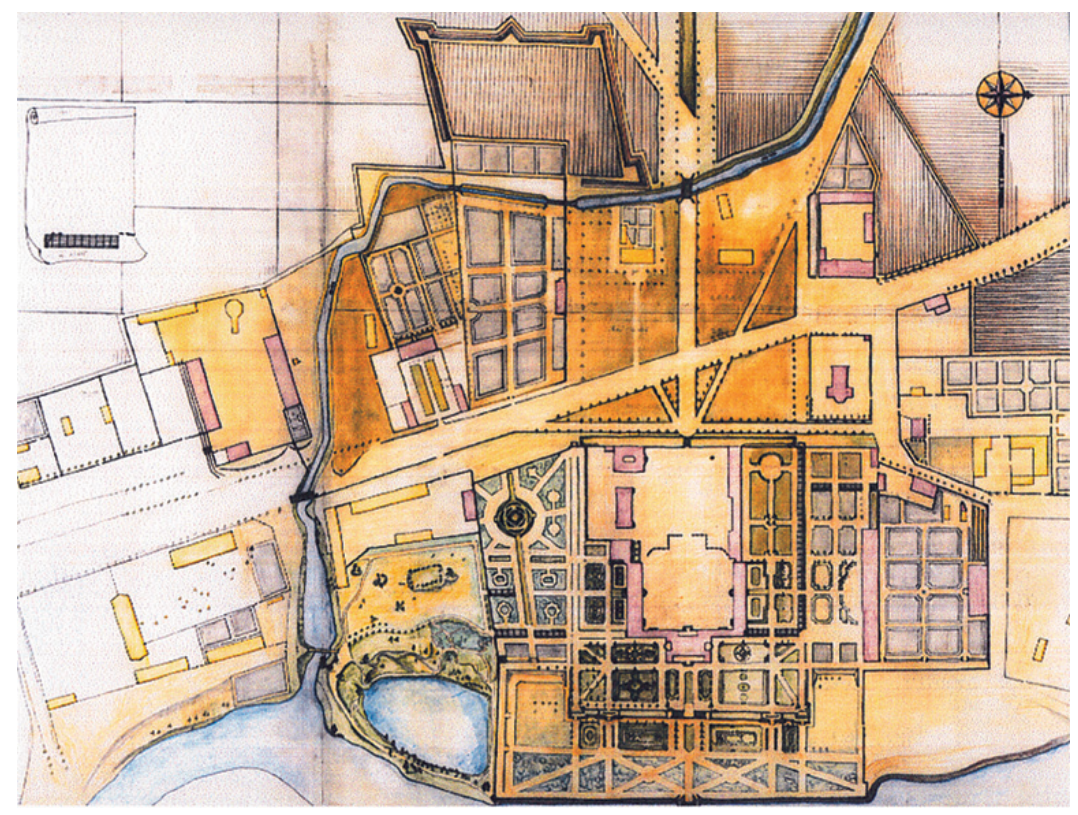

Il. 10. Plan najbliższego otoczenia pałacu wilanowskiego z ogrodem, ok. 1782 r. - przerys wyk. Katarzyna Dankiewicz, wg oryginału z AGAD

\footnotetext{
${ }_{13}$ Pawilon-willa w Bażantarni (obecnie Natolin) przebudowana została w latach 1785-86 pod kierunkiem Piotra Aignera i Stanisława Kostki Potockiego na klasycystyczny pałacyk, który służył parze do 1799 r. kiedy to Izabela Lubomirska opuszczając Warszawę, przekazała swej córce i jej mężowi całe dobra wilanowskie. Pałacyk Rozkosz od 1822 r. był w posiadaniu m. in. Juliana Ursyna Niemcewicza, od którego otrzymał do dzisiaj funkcjonującą nazwę Ursynów.
} 
Przed śmiercią, a więc do 1782 roku, August Czartoryski zdążył jeszcze ukończyć koncepcję regulacji dróg w Wilanowie i wprowadzić nowe wyraziste elementy przestrzenne. Na przedpolu pałacu uporządkowano teren dojazdu, ujęty w czworobok ograniczony ogrodzeniem pałacu, kościoła, austerii i nowych zabudowań kuchni i ogrodu kuchennego. Na zbliżonym do prostokąta przedpolu pojawił się pęk trzech alei obsadzonych drzewami, odchodzących od bramy pałacu. Główna aleja dojazdowa z kanałem królewskim na osi, została poszerzona tuż za mostkiem na potoku służewieckim, poprzez ujęcie kanału z obu stron dwoma równoległymi do niego, prostymi alejami, obsadzonymi czterema rzędami drzew, wyraźnie przestrzennie podkreślając tę oś w krajobrazie. Dodatkowo przed mostkiem aleja zaakcentowana była dwoma symetrycznie po bokach ustawionymi budynkami (drewnianych?) oficyn, które jakby domykały czwarty bok prostokątnego terenu przed bramą wjazdową do pałacu (il. 10). Z przedpola pałacu wyprowadzono jeszcze jedną skośnie biegnącą drogę w kierunku Wolicy, ją także obsadzono drzewami (przebieg dzisiejszej ul. Klimczaka). Omawiany obszar - najbliższego otoczenia pałacu z ogrodem ukazuje plan z ok. 1782 r. ze zbiorów AGAD.

W oparciu o nową oś kompozycyjną - aleję do Służewa, nieco wyżej od obszaru, który obejmuje wspomniany plan, powstał kolejny pęk trzech dróg promienistych: na skrzyżowaniu drogi wilanowskiej (poprowadzonej w kierunku Belwederu i Ujazdowa) z aleją do Służewa. Potwierdza to rozwiązanie plan okolic Wilanowa z ok. 1784 - 86 r. ze zbiorów AGAD i plany późniejsze okolic Warszawy z 1791, 1794 r., 1809 r. i dalsze. Powstał przez powtórzenie zbiegu trzech alej: alei do Służewa jako osi głównej, drogi wilanowskiej - do Łazienek (obecna ul. Belwederska), i drogi w kierunku willi Rozkosz w Służewie - podobnie jak te zbiegające się przy austerii wilanowskiej złożone z: traktu czerniakowskiego, alei do Służewa i osi głównej założenia pałacowego ( por. il. 11, 12). Trakt czerniakowski mając zbliżony kierunek do drogi wilanowskiej, biegnąc niemal równolegle do niej łączył się przy austerii, w tym pierwotnym węźle drogowym Wilanowa, z aleją do Służewa i stał się przeciwwagą dla głównej osi pałacowej z kanałem królewskim, przenosząc ostatecznie ciężar głównej osi kompozycji na Allee Augusta Czartoryskiego - aleję do Służewa. Zamysłem inwestora było, jak się wydaje, planowe powielanie skośnych kierunków wzajemnie równoległych, co w efekcie utworzyło ciekawą kompozycję spiętrzonych układów promienistych, wzorowanych zapewne na tych z Wersalu według André le Nôtre'a.

\subsection{Wilanów w czasach Potockich 1799-1892}

Aleksandra i Stanisław Kostka Potoccy wnieśli do Wilanowa wartości edukacyjne tworząc w 1805 r. w części pałacu muzeum dostępne dla publiczności. Zadbano także o wieś, w której wznoszono nowe zagrody, a w 1809 r. powstała szkoła wiejska. Przekomponowany w duchu klasycyzmu został teren przed pałacowy, gdzie na miejscu dwudzielnego dziedzińca powstał owalny podjazd z trawnikiem i fontanną pośrodku. Na północny-wschód od pałacu, na terenach łąk i lasu łęgowego Potoccy utworzyli park wodno-krajobrazowy nazwany na cześć ich wnuka Morysinkiem. Znalazły się tam ciekawe elementy architektury romantycznej, m. in. podkreślająca oś główną pałacu brama pseudośredniowieczna, oraz klasycyzujący pałacyk z rotundą. Nad jeziorem wilanowskim Henryk Marconi wzniósł także stylizowany budynek pompy, poprowadzona została instalacja wodociągowa zasilająca fontanny przypałacowe. Po śmierci S. K. Potockiego jego żona Aleksandra zleciła utworzenie naprzeciw kościoła cmentarza w Wilanowie, na którym w latach 1821-26 stanęła neogotycka kaplica grobowa według projektu Ch. Piotra Aignera. Kolisty cmentarz przy drodze czerniakowskiej otrzymał ceramiczne ażurowe ogrodzenie projektu Henryka Marconiego. Aleksander Potocki wzniósł w 1836 r. na terenie przedpałacowym neogotyckie mauzoleum ku czci 
swoich rodziców Aleksandry i St. K. Potockich według projektu H. Marconiego, przy głównej bramie wjazdowej. Kościól, do którego poprowadzono prostą drogę od cmentarza także uległ w 1857 r., przebudowie pod kierunkiem H. Marconiego uzyskując formy neobarokowe z dominantą kopuły na skrzyżowaniu naw.

Około połowy XIX w. na przedpolu pałacowym zaszły poważne zmiany w układzie komunikacyjnym, nastąpiło przesunięcie i „,wyprostowanie” traktu czerniakowskiego, biegnącego dotąd skosem - na równoległy do ogrodzenia i bramy pałacu odcinek drogi, regulując przez to teren przedpałacowy, który uzyskał wyraźny kształt prostokątny. Podzielony teraz na krzyż osiową aleją pałacową i nową drogą traktu czerniakowskiego do Powsinka (dzisiejsza ulica St. K. Potockiego), teren przedbramny zawierał cztery kwatery lipowe. Z przedpola usunięto kolidującą z nową drogą kuchnię Czartoryskich i dwa budynki oficyn. Węzłowe połączenie pęku dróg przesunęło się tym samym do miejsca, skąd zaczynał się kanał królewski, z czasem zredukowany - być może częściowo wyschnięty. We wprowadzonej tu zasadzie układu alej promienistych z czasów rządów Augusta Czartoryskiego elementem równie ważnym co sam pałac stał się widoczny z dalekiej perspektywy zdwojony układ dróg promienistych w Wilanowie: osią tego układu była prosta droga do Służewa, konsekwentnie doprowadzona za St. K. Potockiego już na sam szczyt (obecna Al. Wilanowska), co widać wyraźnie na planie Kadetów z 1829 r. (il. 11). Skośnie od niej odchodziły po bokach dwa trakty: droga wilanowska prowadząca z Wilanowa do Łazienek królewskich w Ujazdowie (dzisiejsza Belwederska) Sobieskiego) i krótka, symetryczna do wcześniejszej alejka prowadząca na sam szczyt skarpy - do willi Rozkosz. Drugie analogiczne rozwidlenie znajdowało się na przedpolu pałacowym: od drogi służewskiej odchodziły ukośnie dwa trakty: w kierunku Warszawy trakt czerniakowski (dzisiejsza Wiertnicza/Powsińska) oraz droga do Wolicy (dzisiejsza Klimczaka). Taki schemat komunikacyjny z dwoma pękami alej promienistych ukazuje wspomniany plan Kadetów z 1829 r. i jest on osnową przebiegu dzisiejszych tras ulic.

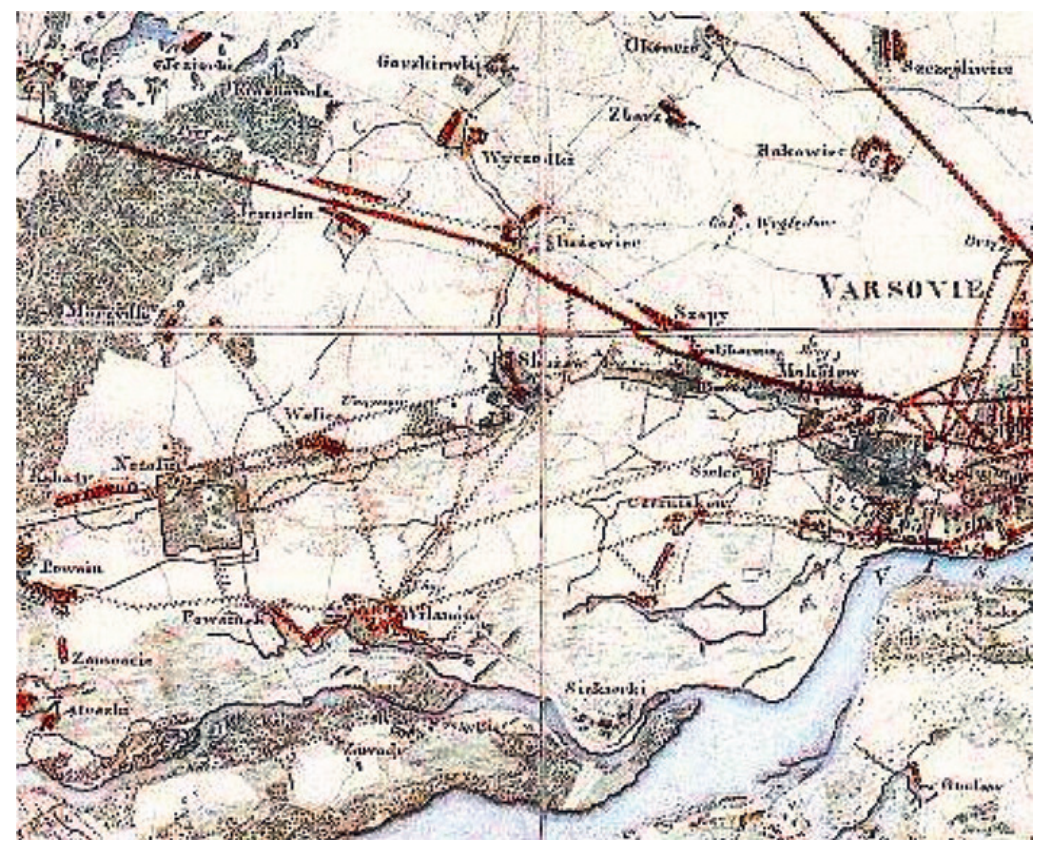

Il. 11. Plan okolic Warszawy, wg Korpusu Kadetów, 1829 r., oryginał w AGAD 
Utworzony przez Czartoryskich i ukończony przez Stanisława Kostkę Potockiego i jego żonę Aleksandrę z Lubomirskich układ komunikacyjny stał się nową jakością urbanistyczną Wilanowa i dodał niezwykle dynamiczną formę do dawnej, barokowej. Przy czym ta ostatnia ulegała stopniowemu zatarciu. Odtąd już nie czytało się w przestrzeni wyizolowanego z otaczającego krajobrazu schematu barokowego założonego na osiach prostopadłych do siebie z dominantą pałacu pośrodku, ponieważ zastąpił go rozbudowany układ spiętrzonych, obsadzonych z obu stron drzewami dróg promienistych o dalekim zasięgu, oparty na osi alei do Służewa (dzisiejsza al. Wilanowska). I mimo tego, że osiowość barokowa została przełamana nie zakłóciło to ogólnego odbioru rezydencji. Otrzymała ona skośnie do pałacu biegnącą, ekspresyjną oprawę utworzoną przez nowy schemat o monumentalnej skali, który dalej podkreślał centrum tego układu - pałac i miał swój początek na jego przedpolu. Układ nowych dróg i alej utworzony poprzez przesunięcie, czy raczej obrócenie i rozciągnięcie kompozycji wzdłuż osi drogi do Służewa wprowadził wielką skalę zamierzenia wiążącego bezpośrednio Wilanów z Warszawą, przez połączenie drogą wilanowską prowadzącą do Łazienek i Belwederu i dalej wąwozem na szczyt skarpy do drogi ujazdowskiej.

Bażantarnię w Kabatach także przekształcono w latach 1821-45 pod kierunkiem Ch. P. Aignera i Henryka Marconiego. Pawilon letni zmieniono na pałac Natolin - od imienia wnuczki Aleksandry i Stanisława Kostki Potockich. Na osi dawnego założenia Elżbiety Sieniawskiej podkreślono aleję prowadzącą do traktu powsińskiego obsadzając ją z obu stron podwójnym rzędem drzew, co świadczyło o kontynuacji tradycji przez kolejnych właścicieli, ale też o chęci podkreślenia swojego znaczenia i zaznaczenia ważnego, z punktu widzenia właścicieli i ich prestiżu, miejsca w przestrzeni krajobrazu.

W II połowie XIX w. powiększony został obszar dóbr wilanowskich o dodatkowy kompleks służewiecki z wsiami Służewiec, Dzbarz, Korzkiew, Jemielin.

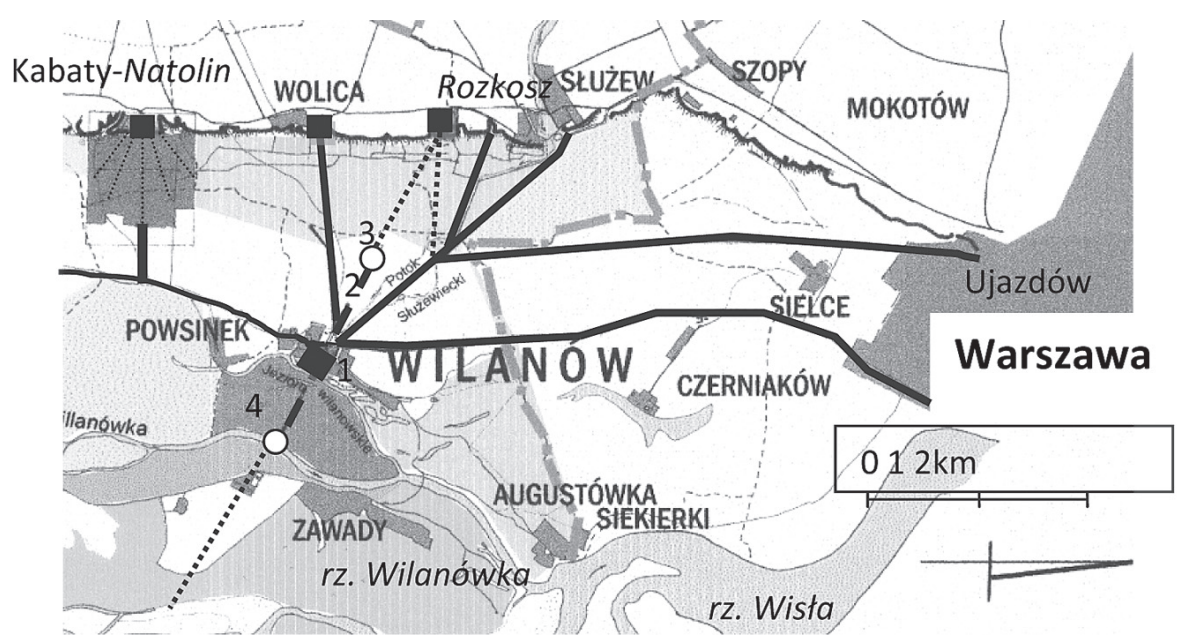

Il. 12. Ukształtowanie przestrzenne w Wilanowie około 1809 roku - oprac. Katarzyna Dankiewicz, wg: Mappa Jeneralna Dóbr Klucza Willanowskiego do projektów Ekonomicznych, Roku 1807, oryginał AGAD, oraz planów okolic Warszawy 1809 r., 1829 r. - oryg. AGAD; od wsi Augustówka w kierunku Służewa widoczny jest fragment granicy klucza wilanowskiego.

Legenda: zachowana oś królewska z akcentami: 1 - pałac, 2 - zredukowany kanał wodny, 3 pasieka królewska, 4 - gospodarstwo rybackie 


\subsection{Braniccy w Wilanowie 1892-1945}

Rok 1892 wniósł w układ komunikacyjny Warszawy i okolic dojazdową kolej żelazną, która prowadziła z Placu Starynkiewicza w Warszawie do Wilanowa i Klarysewa, otaczając łukiem zarówno teren przedpałacowy. W tym czasie dobra wilanowskie należały do spokrewnionego z Aleksandrą Potocką Ksawerego Władysława Branickiego, następnie od 1926 r. do jego syna Adama. W okresie międzywojennym powstał murowany budynek stacyjny kolejki wąskotorowej projektu Konstantego Jakimowicza w tzw. stylu narodowym, który po skasowaniu kolejki po II wojnie światowej pełnił funkcję poczty. Przy cmentarzu zaś znalazła swoje miejsce pętla trolejbusowa - obecnie autobusowa. W latach dwudziestych na skutek zmienionej sytuacji politycznej na Ukrainie Braniccy utracili swe majątki i znaczące źródła dochodów. Dodatkowo świat przeżywał kryzys gospodarczy, co źle wpływało na sytuację finansową Adama Branickiego. Aby utrzymać w dobrej kondycji pałac w Wilanowie wraz z cenną kolekcją sztuki oraz własną rodzinę, przy silnej presji uwłaszczeniowej, w związku z wprowadzaniem reformy rolnej w Polsce po I wojnie, podjął on w latach trzydziestych decyzję o częściowej parcelacji i sprzedaży gruntów. Po raz pierwszy zasada niewychodzenia z jednej ręki dóbr wilanowskich została złamana, nie dotyczyła jednak najcenniejszej części zespołu - klucza wsi w Wilanowie, a jedynie terenów rolnych w Służewie, Moczydle i w Wawrze.

\section{Wilanów - czasy współczesne}

Po II wojnie światowej pozostała większość dóbr wilanowskich została znacjonalizowana, a sam pałac w Wilanowie przeszedł na własność państwa polskiego, stając się oddziałem Muzeum Narodowego. Podobnie inne ważne obiekty, które zachowały się otrzymały nowe reprezentacyjne przeznaczenie. Pałacyk Rozkosz w Ursynowie już w 1921 r. przekazany został narodowi na cele oświatowe, od 1956 r. jest budynkiem rektoratu Szkoły Głównej Gospodarstwa Wiejskiego. Tereny rolne przedpola wilanowskiego i łąki Morysinka przekazano na użytek tejże Szkoły. Pałacyk w Natolinie stał się budynkiem reprezentacyjnym instytucji naukowej, obecnie mieści się tu Centrum Europejskie Natolin. Od 1995 roku muzeum w Wilanowie stało się niezależną od Muzeum Narodowego jednostką podlegającą Ministerstwu Kultury i Dziedzictwa Narodowego, a od 2013 zmieniło nazwę na Muzeum Pałacu Króla Jana III w Wilanowie.

Najnowsze zmiany odnoszą się do realizacji polityki urbanizacyjnej dzielnicy Wilanowa, dążącej do wypełnienia dawnych terenów rolnych i łąkowych tkanką miejską. Postępująca regulacja dróg na rzecz usprawnienia i lepszej przepustowości: poszerzenie Al. Wilanowskiej, Sobieskiego w wielopasmowe trasy, przesunęly w ostatnich trzydziestu latach, (także poprzez przedłużenie Wisłostrady w dawny trakt czerniakowski - ulicę Powsińską i Wiertniczą) drogi o dużym natężeniu ruchu, o znaczeniu ponad lokalnym, niemalże do bram pałacu wilanowskiego. Od kiedy układ dróg komunikacji żelaznej i kołowej zbliżył się do historycznego węzła następowało stopniowe wyłączanie z szybkiego ruchu dróg najbliższych pałacowi - jak to ma miejsce dziś na ul. St. K. Potockiego - z konieczności izolacji pałacu i ogrodów.

\subsection{Miasteczko Wilanów - zrównoważony rozwój przedmieść a Idea Nowej Urbanistyki}

Węzeł w Wilanowie w ostatnim czasie przeżywa nowy etap - na polach i łąkach wilanowskich pomiędzy aleją Wilanowską, ulicą Przyczółkową, Natolinem a skarpą warszawską powstaje rozległy kompleks mieszkaniowo-usługowy pod nazwą Miasteczko Wilanów. 
Zamierzenie to realizowane od 2002 roku w całości przez prywatnego inwestora - firmę Prokom Investments ${ }^{14}$, początkowo obejmować miało obszar ok. 170 ha najbliższy pałacowi i trwać 10 lat, jednak obecnie wydaje się stale rozszerzać na pozostałe tereny na błoniach, pozostawiając nieodparte wrażenie niedokończonej inwestycji.

Rozbudowę w Wilanowie umożliwił Plan Ogólny Zagospodarowania Przestrzennego m.st. Warszawy z 1992 roku, który przeznaczał obszar blisko 500 ha terenu na błoniach wilanowskich (znajdującego się między ul. Przyczółkową, skarpą i al. Wilanowską) pod budownictwo mieszkaniowo-usługowe. Zorganizowany przez Radę Gminy Wilanów w 1996 roku konkurs urbanistyczny na koncepcję zagospodarowania Wilanowa Zachodniego [21] wyłonił zwycięską pracę autorstwa architekta Pawła Detko z zespołem. Zwycięska koncepcja wprowadzała jako główny element kompozycji urbanistycznej trójpromienny pęk alej odchodzących z przedpola pałacu, z kanałem królewskim pośrodku. Tym samym zwracając uwagę na historyczny kontekst podejmowanej problematyki powrócono niejako do pierwotnej barokowej formy królewskiej kompozycji, z osią główną założenia idącą prostopadle do pałacu wilanowskiego. Takie nawiązanie było odejściem od koncepcji z końca XVIII wieku i kończonej w początkach XIX. Wówczas to, w czasach Czartoryskich, jak wiemy, kanał królewski uległ już zatarciu, gdyż wówczas to inne trzy promieniste aleje wyznaczały schemat układu komunikacyjnego: droga do Wolicy, droga do Służewa i trakt czerniakowski, kręgosłupem zaś całości była aleja Wilanowska, czyli droga do Służewa, ukośna w stosunku do kanału królewskiego.

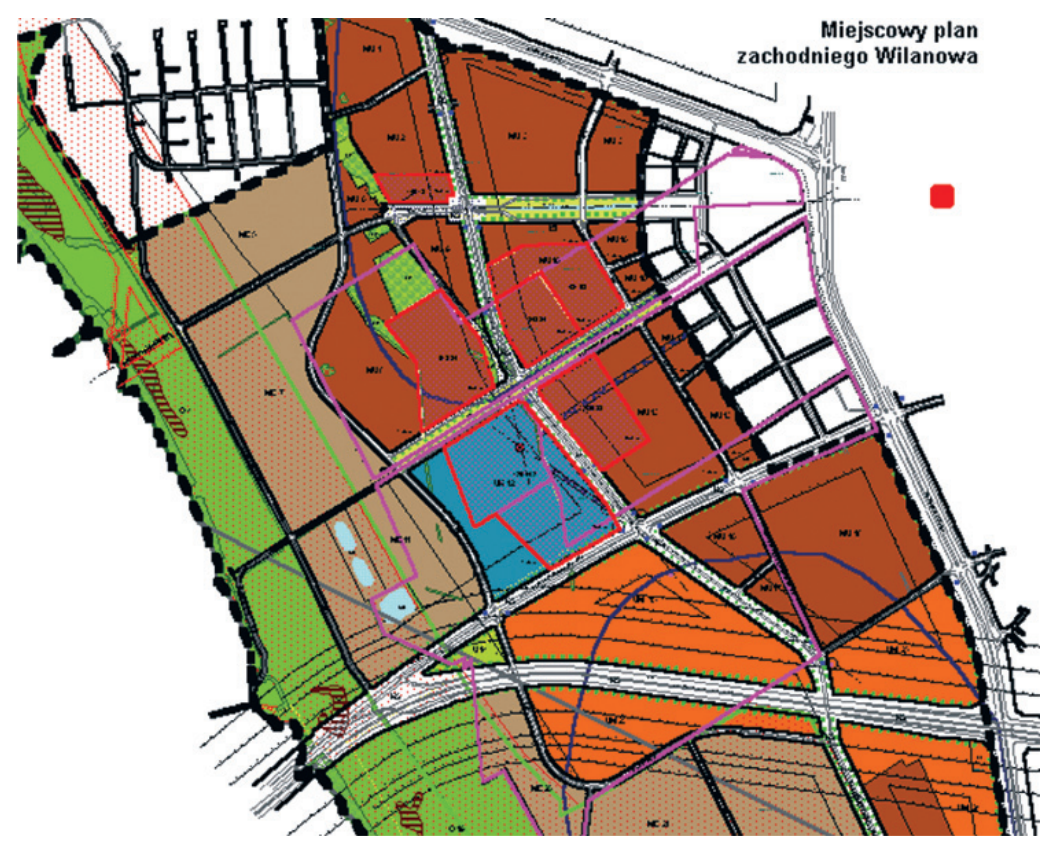

Il. 13. Plan miejscowy Wilanowa Zachodniego, 2000 r., za: www. um.waw.pl

Autorzy zwycięskiej pracy w konkursie z 1996 roku otrzymali następnie od władz samorządowych dzielnicy zamówienie na wykonanie Planu Miejscowego Zagospodarowania

${ }^{14}$ Od 2006 roku cele i zadania inwestora generalnego Prokom Investments przejęła firma Polnord. 
Przestrzennego przedpola pałacowego, zaś plan pozostałego obszaru Wilanowa Zachodniego wykonał zespół Biura Planowania i Rozwoju Warszawy. Oba stały się obowiązujące w 2001 roku. Główną osią powiązania historycznego założenia w Wilanowie i nowego osiedla mieszkaniowego stała się oś barokowego założenia pałacu wilanowskiego. Poza szeroką aleją główną z kanałem na jej osi nie widać widocznych odniesień do barokowych rozwiązań, które istniały tu pod koniec XVII wieku czy w latach trzydziestych XVIII w. W omawianej koncepcji trudno doszukać się wyraźnego akcentowania tej na nowo ożywionej koncepcji, co dobrze wpisywałoby się w nową urbanistykę - poprzez place, zespoły placów, fontanny, fragmenty krajobrazowe, parkowe, charakterystyczne obiekty (istniała tu przecież pasieka królewska), czego można spodziewać się po nawiązującej do baroku formie kompozycji przestrzennej. Samo poszerzenie osi głównej i uformowanie na środkowym odcinku jako ciąg pieszo-jezdny podkreślony zadrzewieniem może nie przynieść spodziewanego efektu zespolenia obu obszarów. Zakończenie osi królewskiej nastąpiło w formie skrzyżowania (trudno dociec czy miejsce to zostało wybrane w wyniku głębszych analiz historycznych) z al. Rzeczypospolitej. Aleja ta wprowadzona została jako główna arteria na tym obszarze i stała się - prostym przedłużeniem ul. Belwederskiej (dawnej drogi wilanowskiej), a więc nowym kierunkiem wprowadzonym do układu osi barokowych, która skośnie przebiega aż do placu-węzła z ul. Klimczaka, gdzie zaplanowano miejsce pod Świątynię Opatrzności Bożej - dominantę tego obszaru (teren oznaczony kolorem niebieskim na planie miejscowym, por. il. 13).

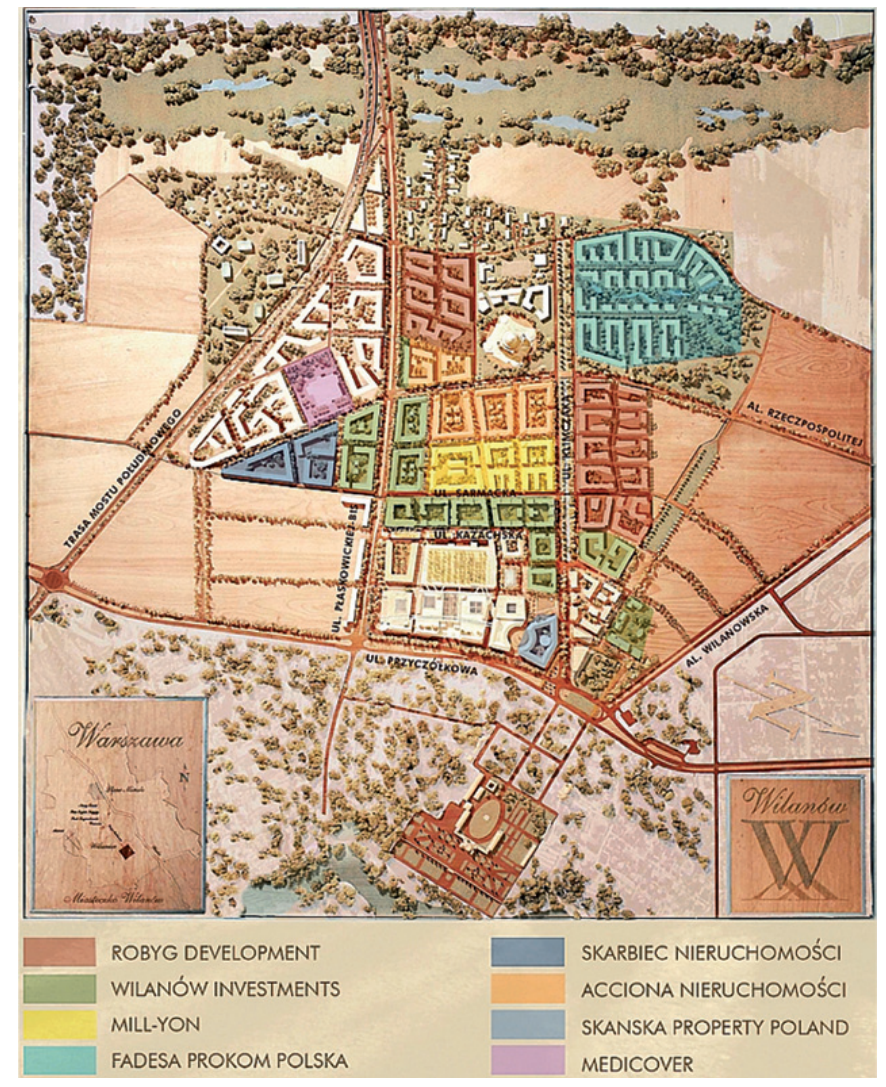

Il. 14. Fragment folderu Miasteczka Wilanów, 2005 r. z koncepcją Master Planu 
Akcentem zupełnie nowym na osi królewskiej stał się w 2000 r. wzniesiony przez władze dzielnicy budynek Ratusza ${ }^{15}$, usytuowany tuż przy jej początku, niczym „brama” do miasta, o nowoczesnej architekturze stał się atrakcyjną i mocną (może zbyt mocną?) dominantą, zlokalizowaną blisko pałacu.

Firma Prokom przystępując do realizacji przedsięwzięcie pod nazwą Miasteczko Wilanów zaangażowała na wstępie, chcąc oprzeć się na uznanym autorytecie w dziedzinie zrównoważonego rozwoju miasta, amerykańskiego urbanistę Guy Perry'ego do wykonania Master Planu. W efekcie rozwinięto koncepcję urbanistyczną w oparciu o plan miejscowy i formy bliskie tradycyjnej architekturze miejskiej, o niskiej intensywności zabudowy i niewielkiej skali budynków, co odpowiadałoby strefie przedmieścia. Projektowany obszar podzielono na czworokątne kwartały zabudowy. Przez stosowanie zabudowy obrzeżnej utworzono kameralne wnętrza urbanistyczne [22] z udziałem zieleni wzdłuż ciągów pieszych ${ }^{16}$. Osnową założenia były trzy promieniste drogi prowadzące od ul. Przyczółkowej, naprzeciw pałacu w Wilanowie - osie widokowe w postaci ciągów pieszo-jezdnych z nasadzeniami. Kanał w projekcie został poszerzony i wydłużony (nadal jednak trudno powiedzieć dlaczego w danym miejscu się on kończy, brak też wydaje się przestrzennnego akcentu tego miejsca) zaś aleja Wilanowska (dawna droga do Służewa) i ulica Klimczaka (dawna droga do Wolicy) pozostały ukośnie, symetrycznie po bokach kanału.

Prokom bazując na wspomnianym Master Planie zaangażował do współpracy kilkanaście czołowych polskich pracowni projektowych oraz architektów [23], co w zamierzeniu zapobiegać miało monotonii architektury, a także zapewniać jej wysoką jakość. Realizacja tak dużego zamierzenia budowlanego wymusiła konieczność współpracy z Prokom Investments innych prywatnych firm: Robyg Development, Wilanów Investments, Fadesa, Skarbiec Nieruchomości. Prokom jako inwestor główny wykonał infrastrukturę komunalną: kolektor sanitarny do oczyszczalni ścieków „Południe”, magistralę wodociągową, sieci wodno-kanalizacyjne dla swoich inwestycji, przebudowę Rowu Wolickiego wraz z ulicą Klimczaka, budowę dróg dojazdowych do realizowanych inwestycji.

Koncepcja Perry'ego otrzymała w 2010 roku prestiżową nagrodę urbanistyczną Urban Land Institute Global Award, a wcześniej w 2008 roku - po częściowej realizacji - „Nagrodę za Doskonałość" ISOCARP 2008 (International Society of City and Regional Planners), za oparty na idei Nowej Urbanistyki, kontrolowany zrównoważony rozwój przedmieść i nawiązanie do tradycyjnych form, odwołania do historycznego sąsiedztwa.

Master Plan opierając się na ustaleniach Planów Miejscowych obejmował cały obszar przeznaczony pod zabudowę, zaś realizacja zadania przez Prokom pod nazwą Miasteczko Wilanów odnosiła się do (pierwotnie zakupionych przez tę spółkę gruntów na błoniach wilanowskich) 169 hektarów na Przedpolu Pałacowym, pomiędzy osią królewską i ul. Klimczaka. W przytoczonej na łamach czasopisma „Urbanista” ważnej dyskusji, warszawscy architekci i urbaniści byli zdania, by nie rozwijać dalej Miasteczka Wilanów [24] i ukończyć pierwotne zamierzenie, co usprawniłoby zamykanie kolejnych etapów i całych fragmentów osiedla. Działania jednokierunkowe oparte na realizacji wyłącznie zespołów mieszkaniowych, wprowadzały na ten teren nowych mieszkańców, którzy z kolei oczekiwali rozwiązań całościowych, pełnej infrastruktury, zaopatrzenia, usług, służb zdrowia, szkół itp.

\footnotetext{
15 Autorem projektu Ratusza Dzielnicy Wilanów wybudowanego w latach 2000-2014 jest pracownia Kuryłowicz\&Associates.

16 Zwarta zabudowa obrzeżna jest jedną $\mathrm{z}$ form przeciwdziałania niekontrolowanemu rozlewaniu się miast $\mathrm{i}$ chaotycznej zabudowy przedmieść i terenów podmiejskich, jako metoda wprowadzania ładu przestrzennego.
} 
Autor Master Planu Guy Perry zakładał dla Miasteczka Wilanów rozwiązania bliskie formom przestrzeni publicznych wielkomiejskich dzielnic Londynu [25]. Dobrze są znane przykłady takich fragmentów miast jak np.: paryskich placów (Des Vosges, plac Vendôme, plac Gwiazdy - dzisiejszy plac Charles de Gaulla), XVIII wiecznych przykładów urbanistyki mieszkaniowej z Bath, wiążących zwartą niską zabudowę mieszkaniową z zielenią trawników i rozległych krajobrazów, czy berliński przykład promenady Unter den Linden - z elegancką zabudową XVIII-XIX wieczną i z budynkami o przeznaczeniu publicznym. Współczesne miasta ubogacane są w wyrazisty sposób dostosowany do potrzeb i możliwości, w przestrzeń publiczną wiążącą i przyciągającą różne jego strefy. W literaturze opisywane są wnętrza urbanistyczne, kompozycje złożone z małych shierarchizowanych centrów o funkcjach publicznych służących kontaktom społecznym, po funkcje handlowe, również takie jak fresh markety - „targi rolne” z produktami spożywczymi bezpośrednio od rolników, hodowców, u nas doceniane i tak popularne za granicą (otwarte raz lub kilka razy w tygodniu) ${ }^{17}$. Potrafimy sobie wyobrazić takie elementy w nowej urbanistyce dzielnicy, czytelne naprowadzenia, dominanty, place, tereny publiczne, parki, powiązane ciągami pieszymi z głównym historyzującym układem, z dostępnymi „side walk café” - kawiarniami przyulicznymi, czy mającymi swój klimat zacisznymi eleganckimi restauracjami, na boku głównych ciągów [26].

Choć Master Plan rozwijał założenia planu miejscowego wprowadzając wyraźną strukturę miejską na obszar Miasteczka Wilanów, nie rozwiązał jak się wydaje problemu ciągłości obu stref - dawnej i nowej w Wilanowie. Pewne tereny pozostały niedookreślone, (stając się rezerwą pod przyszłe budownictwo ?). Brak graficznie określonych obszarów o funkcjach uzupełniających - szczególnie rekreacyjnych, publicznych które mogłyby wypełnić lukę pomiędzy dwoma obszarami: pałacu i nowego Miasteczka, kontynuując, dopowiadając historię poprzez powrót do dawnego ukształtowania i przeznaczenia tych terenów.

\subsection{Stan obecny rozwoju przedmieścia}

Budowa Miasteczka przewidziana była na 8-10 lat, jednak nadal przeciąga się, a priorytet ekonomiczny jest wciąż bardziej widoczny niż cel publiczny, który stanowić miał klucz do sukcesu tej inwestycji. Widoczne są powstałe jednostki mieszkalne, zaś przestrzeń publiczna nie wykazuje ciągłości i odpowiedniego wyposażenia w funkcje. Jak wskazała Krystyna Solarek: „Miasteczko Wilanów powstaje (na razie) bez infrastruktury społecznej. Sukcesja terenów podporządkowana wyłącznie czynnikom rynku budowlanego może powodować powstawanie struktur kalekich"18. Prokom jako główny inwestor z własnej inicjatywy podejmował próby ulokowania obiektów służących celom publicznym, co wiązało się ze zmianą strategii ekonomicznej firm i wydłużaniem procesu budowlanego (także na skutek negocjacji w partycypacji władz dzielnicy w tych inwestycjach). Oddalające się w czasie lub niezrealizowane inwestycje o charakterze publicznym nie ułatwiają życia mieszkańcom, którzy oczekiwali wyższego standardu i konkretnych funkcji w swym otoczeniu. Powtarzając za uznanym architektem oraz teoretykiem architektury i urbanistyki współczesnej Leonem Krierem, że: „, plan urbanistyczny powinien być trójwymiarową syntezą, ramą legislacyjną i społeczną, pozwalającą na optymalny rozwój interesów jednostki i gwarantującą jej samodzielność" [27], zastanawia więc fakt, dlaczego nie dzieje się tak w Miasteczku. Bo prze-

\footnotetext{
${ }^{17}$ Sam gospodarz Wilanowa - król Jan III Sobieski przywiązywał do upraw dużą wagę, osobiście doglądając dojrzewających w ogrodzie wilanowskim owoców i warzyw.

${ }^{18}$ Krystyna Solarek, Rozwój urbanistyczny Warszawy - plany i rzeczywistość, [dostęp: https:// docplayer.pl, 17.09.2017].
} 
cież (znów za L. Krierem): „Miasto to nie wynik przypadku, lecz klarownych wizji i celów, bez których miejska cywilizacja nie mogłaby powstać. Innymi słowy, miasto jest wytworem ludzkiego ducha”. Całe zamierzenie zamiast zamknąć się w przewidzianym obszarze 169 ha i 10 lat budowy, zaczęło rozciągać się ( być może już bezplanowo?) na okoliczne dołączane tereny, co przy niedostatecznej infrastrukturze drogowej, pociąga za sobą ciągły zły stan dróg i poczucie mieszkańców, że żyją obok placów budowy.

Teren Wilanowa Zachodniego w sąsiedztwie Miasteczka Wilanów, podlega wciąż dalszej rozbudowie, w której uczestniczą niezależni deweloperzy, nabywający nowe działki. Prokom - obecnie Polnord stara się aby ich forma wpisywała się w założenia Master Planu, (czy wystarczają tylko te założenia?) co także wiąże się z osobnymi negocjacjami i rozciąganiem realizacji.

Istnieje przy tym obawa - czy na tak dużym obszarze, podmokłym niegdyś, nie zostanie wykonane osuszenie terenu ${ }^{19}$, ze względu na konieczność nawet płytkiego, posadowienia dużej liczby budynków, co negatywnie odbiłoby się na funkcjonowaniu sadzawek, fontann i systemu wodnego na przedpolu i przy Pałacu w Wilanowie. Nie do końca jasne jest w jakiej formie zostanie wykonane zakończenie głównej osi królewskiej - obecnie jest to „,koniec drogi” dojazdowej do budynku. Osie widokowe kierujące wzrok ku konkretnym „obrazom", widoczne powinny być także z oddali w krajobrazie. Osie nie są obsadzone, jak dotąd, a częściowo wykonane fragmentaryczne nasadzenia są w zbyt małej skali - nie dają cienia, na co uskarżają się mieszkańcy, których głos wydaje się mocny - oblegając fora internetowe i gazetki społecznościowe - zdaje się być mało słyszalny dla władz i inwestorów, których także powinien zastanawiać fakt utrwalającego się od kilku lat spadku cen metra kwadratowego mieszkań w Miasteczku Wilanów.

\subsection{Oświata, kultura, zdrowie w Miasteczku}

Obecnie dzielnica Wilanów przekroczyła już, przewidywanąa na zakończenie całej inwestycji, liczbę mieszkańców. Wynosi ona (dane na 2017 rok, wg wikipedii i stron internetowych poszczególnych dzielnic Warszawy) ponad 36 tysięcy osób, z czego w samym Miasteczku Wilanów przybyło w ostatnich latach około 15 tysięcy mieszkańców. Przyjmując taką liczbę ludności zamieszkałą na terenie (niedokończonej jeszcze w 100\% budowy Miasteczka) około 150 ha $\left(1,5 \mathrm{~km}^{2}\right)$, to wskaźnik zagęszczenia wynoszący 8000 mieszkańców/km², osiągnięty w tej części dzielnicy, plasuje ją na drugim miejscu w Warszawie pod względem największego zagęszczenia ludności - po dzielnicy Ochota, (Ochota - 8600 mieszkańców/1 km², Śródmieście - 7598 mieszkańców/km², Żoliborz - 5882 mieszkańców/ $\mathrm{km}^{2}$ ). Przy czym Ochota w Warszawie jest bogata w infrastrukturę społeczną, posiada m. in.: 23 przedszkola, 13 szkół podstawowych, 10 gimnazjów (dane z 2016 roku), 5 techników, 5 LO, 2 szkoły policealne, 6 szkół wyższych, 3 szpitale, 2 teatry, domy studenckie, biblioteki, 2 hale targowe, nie licząc mniejszych obiektów handlowo-usługowych, urzędów itp. W dzielnicy Żoliborz zaś znajduje się m. in.: 6 parków, 5 kościołów, szkoła wyższa, 3 licea, przedszkola i kilka szkół podstawowych, przychodnie zdrowia, centrum olimpijskie, teatr, kino, stacja metra.

\footnotetext{
19 Kanał Królewski już teraz okresowo wysycha i brak w nim wody. Por.: Justyna Pakuła, Miasteczko Wilanów studium przypadku, praca magisterska wykonana na Wydziale Polonistyki Uniwersytetu Warszawskiego, 2015, [dostęp: https://depot.ceon.pl, 17.09.2017], s. 27.

20 W Studium uwarunkowań i kierunków zagospodarowania Gminy Warszawa-Wilanów wykonanym w 1999 roku w związku z planowanym rozwojem Wilanowa Zachodniego, przewidywano docelowo powiększenie liczby mieszkańców gminy do 35 tysięcy.
} 

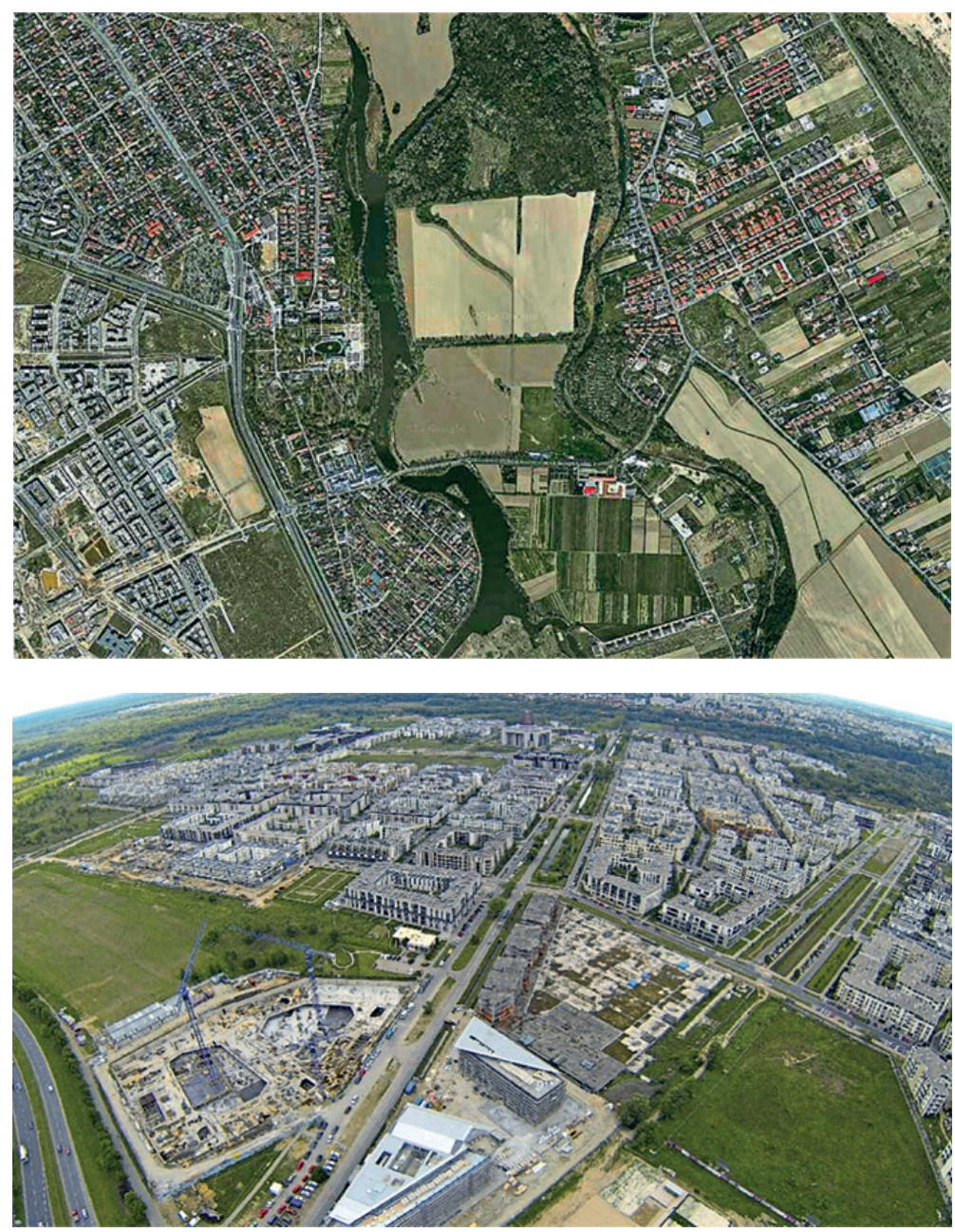

Il. 15,16. Wilanów - mapy Google, 2017 r.

Miasteczko Wilanów boryka się więc z niedoinwestowaniem w obszarze potrzeb o charakterze społecznym. Do 2017 r. wybudowane zostały lub są na ukończeniu: ratusz, przedszkole i żłobek prywatny, przedszkole i szkoła podstawowa publiczna, prywatna szkoła niemiecka im. Willy’ego Brandta, szpital Medicover, Świątynia Opatrzności Bożej i dom kultury z biblioteką. Nadal nie są to zadowalające udogodnienia dla rozwijającej się młodej populacji mieszkańców. Potrzebne będą także obiekty dla osób starszych (większa ilość urzędów, przychodni, aptek, specjalistycznej opieki zdrowotnej, rehabilitacyjnej, biblioteki, kina, itp.) Problemem jest także nie dość sprawna komunikacja - brak wszystkich dróg (nie ma połączenia z Ursynowem i Natolinem, także nieukończona jest sieć ulic lokalnych), niedokończone ścieżki rowerowe, brak parkingów naziemnych, słabe oświetlenie ulic, niedostateczna komunikacja miejska (3 linie autobusowe tylko na głównej ulicy miasteczka al. Rzeczypospolitej). Brak potrzebnej pełnej infrastruktury społecznej, komunalnej i publicznej może w konsekwencji zaniżyć wartość nieruchomości na tym terenie i negatywnie odbić się na wizerunku tej nowoczesnej w zamierzeniu inwestycji. 


\subsection{Obiekt kultu religijnego w Miasteczku Wilanów}

W ogólnopolskim konkursie zorganizowanym w 1999 roku przez Fundację Budowy Świątyni Opatrzności Bożej (ŚOB) w Wilanowie oraz Stowarzyszenie Architektów Polskich na koncepcję świątyni, zwyciężyła w 2000 roku, uzyskując skierowanie do realizacji, praca architekta Marka Budzyńskiego (autora m. in. Gmachu Sądu Najwyższego i Biblioteki Uniwersytetu Warszawskiego). Jednakże odsunięto ją wkrótce od realizacji jako zbyt odległą od potrzeb samych duchownych, oraz zwolenników tradycyjnych form kościoła. Koncepcja M. Budzyńskiego przedstawiała zespół budowli (kościoła, instytutu, budynku rekolekcyjno parafialnego) częściowo zagłębionych w gruncie, położonych w urozmaiconym krajobrazie pokrytym roślinnością, z kościołem, który poprzedzał plac pokryty cienką warstwą wody (wypompowywanej na potrzeby uroczystości odbywających się na placu). Wszystkie te elementy tworzą symboliczne autorskie odniesienia do pojęcia wiary i mają zbliżać wiernych ponad podziałami, nawet religijnymi. Bo trudno ten kościół jednoznacznie odczytać - sam architekt zaznacza, że jego forma jest wieloznaczna ${ }^{21}$ : „,kryształu i drzewa, namiotu i góry, sielskości i potęgi”. Koncepcja powiązania architektury z krajobrazem, a także zastosowanie ekologicznych nowoczesnych rozwiązań technicznych, które przedstawił autor zwycięskiej pracy wzbudziły uznanie wielu środowisk, i wiele lat po konkursie nie słabną internetowe komentarze. Wśród przeciwników przeważały opinie o zbyt odległej od tradycyjnych formie i niezrozumiałej dla odbiorców koncepcji zmuszającej do indywidualnego odkrywania znaczeń symboli, niejasno rozmieszczonych w zaprojektowanej przestrzeni, oraz że byłby to projekt zbyt drogi. W 2001 roku Fundacja przystąpiła do zorganizowania drugiego konkursu - tym razem zamkniętego, dla wybranych zespołów, podając za wzór odniesienia klasycystyczny projekt kościoła według Jakuba Kubickiego z 1792 r. Wygrała praca Lecha i Wojciecha Szymborskich, którzy sami wskazują na trzy elementy składowe ich koncepcji - krzyż, koło i promienie światła ${ }^{22}$. Należy dodać jeszcze kwadrat, w który w planie wpisane jest koło i krzyż grecki. Świątynia zarówno przed jak i po wybudowaniu wzbudza wiele emocji, zarówno wśród architektów jak i mieszkańców miasta, swą skalą i formą. Przetoczyła się ponadto w prasie i w internetowych czasopismach i forach burzliwa dyskusja odnosząca się do arbitralnej oceny prac konkursowych przez hierarchów kościoła katolickiego i wyłonienia innego niż zwycięski, projektu do realizacji, co zapewne wpływa na akceptację tego zamierzenia przez mieszkańców miasta.
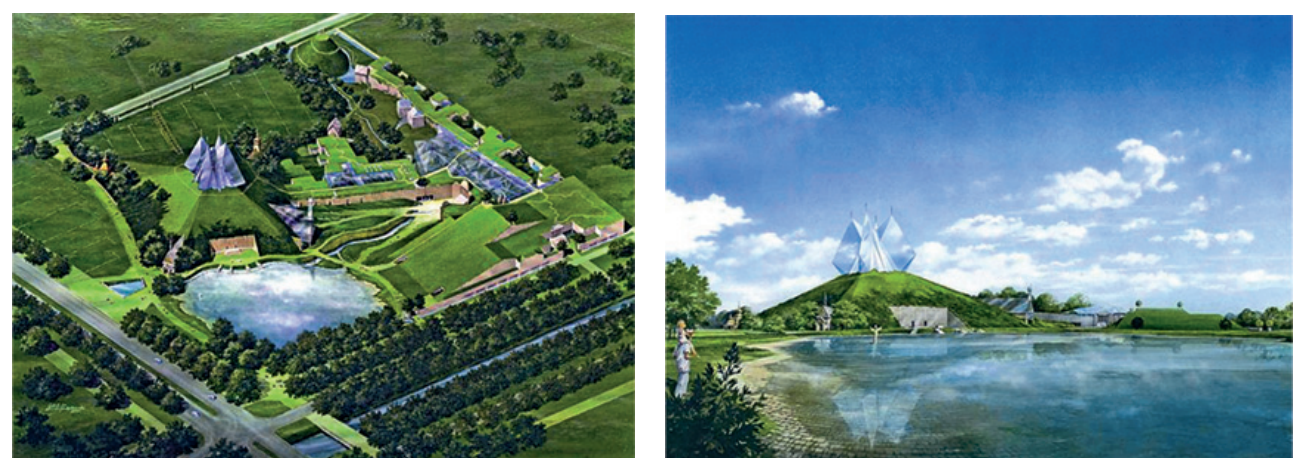

Il. 17, 18. Proj. Marek Budzyński, koncepcja konkursowa ŚOB, 2000 r. - miejsce I równorzędne, praca zgłoszona do realizacji

${ }_{21}$ za: futuwawa.pl, dostęp: 18.09.2017 - Świątynia Opatrzności Bożej.

22 za: www.bryla.pl [dostęp: 18.09.2017] -Projekt Świątynii w stowach architektów. 


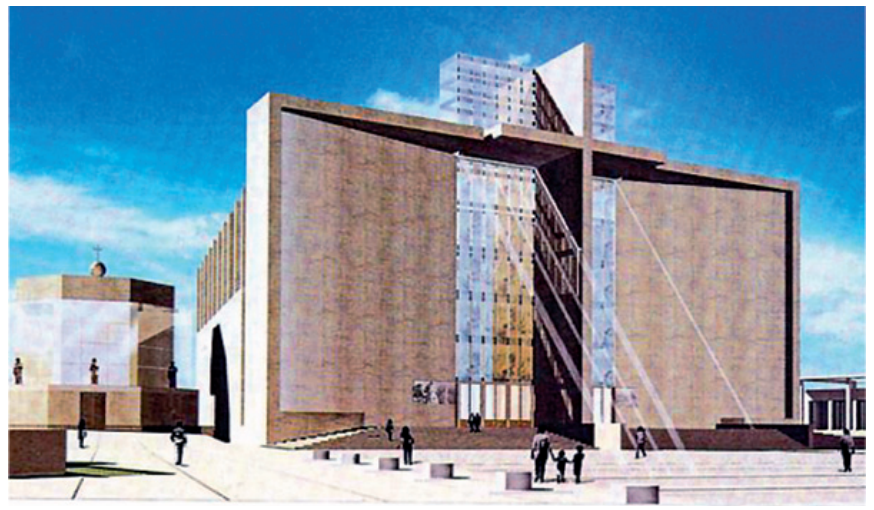

Il. 19. proj. W. i L. Szymborscy i Jacek Zielonka, koncepcja konkursowa ŚOB, 2000 r. - miejsce I równorzędne

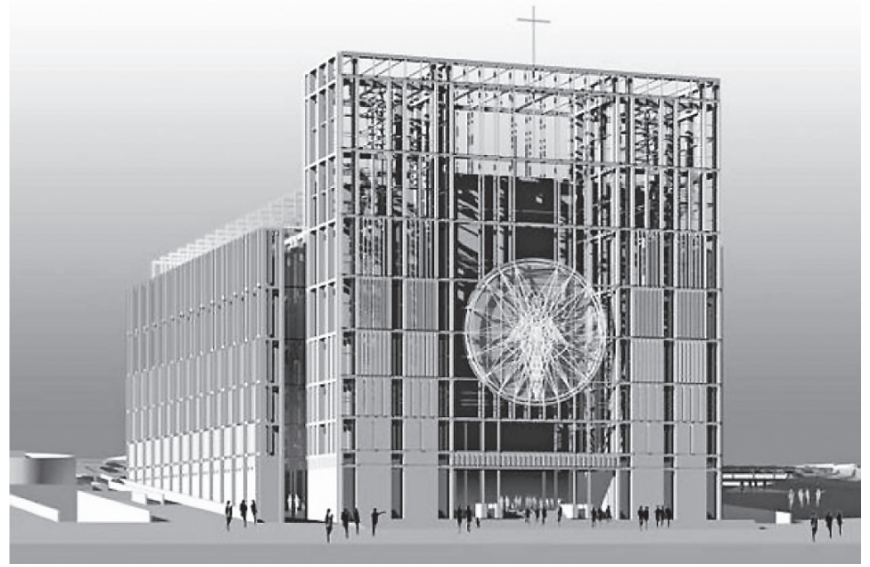

Il. 20. proj. zespół JEMS, koncepcja konkursowa ŚOB, 2000 r. - miejsce I równorzędne

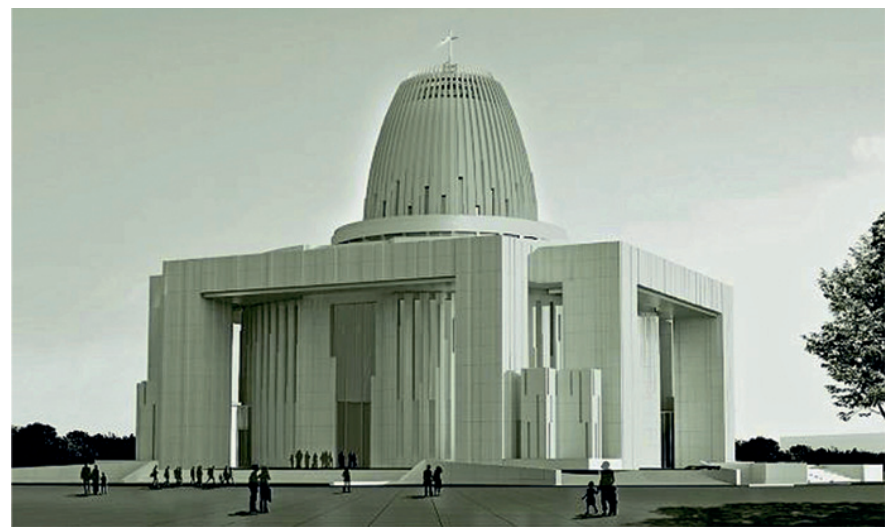

I1. 21. proj. Wojciech i Lech Szymborscy, koncepcja konkursowa ŚOB, 2001 r. - I miejsce i praca wybrana do realizacji. Za: http://www.bryla.pl/bryla/56,85301,12900805,Dzieje_Swiatyni_ Opatrznosci_Bozej_WIZUALIZACJE_FOTO_html 
Prokom Investments przekazał Fundacji Budowy Świątyni sześciohektarowy grunt pod budowę Świątyni Opatrzności Bożej (ŚOB) przy skrzyżowaniu głównych ulic: Klimczaka i al. Rzeczypospolitej, gdzie została ona wzniesiona w latach 2002 - 2016, jako „wyraz wdzięczności narodu wobec Boga za dar wolności”. Monumentalnej budowli o boku 84 metrów i wysokości (wraz z kopułą pokrytą miedzianą blachą) 75 metrów, o ostro zarysowanych kątach prostych, surowej fakturze ścian, nie cechuje bogactwo detalu, raczej jest jego programowy brak. Bryła przemawia do odbiorców w całej swej masie, ciężką i nieco tajemniczą, niedostępną formą,. Przenikający się prostopadłościan z walcem, z kopułą o wydłużonym eliptycznym przekroju, sprawiają wrażenie dostojnej powagi (bliższej może charakterowi mauzoleum niż kościoła), co nie dość wyraźnie harmonizuje ze skalą i pogodną elegancją pobliskiej zabudowy Miasteczka Wilanów, przy ul. Klimczaka i al. Rzeczypospolitej. Świątynia pozostaje wyobcowana z otaczającej zabudowy, samotna przy wielkim pustym betonowym placu bez ławek, zieleni. Ożywia się jedynie wieczorami, podświetlana kolorowymi iluminacjami, a także z okazji uroczystości religijnych i państwowych, co wówczas (z braku parkingów) utrudnia ruch lokalny ${ }^{23}$. Ponadto podnoszona jest w mediach kwestia olbrzymich kosztów jej budowy sięgających 200 milionów złotych, zebranych w większości z dobrowolnych składek, a także dalszych potrzeb związanych z wykończeniem świątyni ${ }^{24}$. Inwestycja, nieukończona ale oddana w 2016 roku do użytku, jest drugą, po ukończonym w 2014 roku Ratuszu, o cechach dominanty pośród niskiej zabudowy mieszkaniowej.

\section{Wnioski}

Miasteczko Wilanów odnosi korzyść z nazwy, realizując w założeniu przyjazny wizerunkowo wariant zabudowy. Gubi go jednak zbytnia homogeniczność, którą przełamać by mogły elementy „miasta zielonego” [28]: parki (także tematyczne), formy ogrodowe, które stanowiłyby substytut utraconego krajobrazu, podkreślając historyczny układ osiowy, płynnie komponując się z zastanym tu zespołem pałacowo-ogrodowym w Wilanowie ${ }^{25}$. Przy partycypacji miasta i współdziałaniu inwestorów jest nadzieja na realizację zamierzeń sprawnego pod względem funkcjonalnym i nowoczesnego fragmentu miasta, które w założeniu miało tu powstać, łącząc dawne i współczesne formy przestrzeni.

Poszukując synergii w rozwoju Wilanowa właściwym byłby przywołany i częściowo odtworzony w krajobrazie Miasteczka, dawny charakter błoni wilanowskich, podmiejskich rekreacyjnych terenów. Brak jest bowiem płynnego powiązania historycznego założenia z nowym (zieleń parkowo-ogrodowa mogłaby uzupełnić węzeł - plac powstały przy ratuszu - naprzeciw pałacu, a osie widokowe mogłyby otrzymać zieloną oprawę ze szpalerów wysokich drzew).

Miasteczko korzysta z prestiżu miejsca i wciąż rośnie. Odczuwalny ogólny stan zmęczenia tym procesem mógłby przerwać oddawany do użytku fragment za fragmentem zaplanowanego, kompletnego, wyposażonego w szereg funkcji uzupełniających taką jednostkę, zadania, na co już wiele lat wcześniej zwracali uwagę urbaniści.

\footnotetext{
${ }^{23}$ za: Pakuła J., op. cit., [dostęp: https://depot.ceon.pl, 17.09.2017], s. 39-40.

24 Wojtczuk M., Świątynia Opatrzności Bożej. Kościół droższy niż bazylika w Licheniu, „Magazyn Stołeczny” 10.11.2016, za: https://.warszawa.wyborcza.pl, [dostęp: 18.09.2017].

25 Takie elementy zawiera również koncepcja „miasta spójnego” - zachowującego spójność z częścią historyczną. Krystyna Solarek zwraca uwagę na rosnącą, ze względu na brak innych czynników, rolę centrów handlowych, które stają się współczesnymi węzłami i punktami orientacyjnymi w przestrzeni - miejsc największej aktywności społecznej w strefach podmiejskich.
} 
Pałac w Wilanowie stanowi główny punkt odniesienia dla inwestorów i magnes przyciągający potencjalnych mieszkańców do tego rejonu miasta. Muzeum zyskało nowych gości, otrzymało reklamę i korzysta z dobrej koniunktury na organizowanie widowisk, spektakli, koncertów i przedsięwzięć kulturalnych przyciągających widzów wywodzących się z pewnością także z lokalnej społeczności. Dwa organizmy starają się wzajemnie rozwijać, wspierać i uzupełniać, co jest lub powinno być czytelne i możliwe na znacznie większą skalę, obejmującą także tereny dawnych błoni.

Nowa zabudowa miejska wraz z zabudową uzupełniającą: urzędy, usługi, oświata, kultura, przestrzeń publiczna, wpisując się w rejon o historycznej wartości uzyska tym więcej im bardziej wykorzysta właściwie zinterpretowane dziedzictwo historyczne, zachowane i utrwalone lub odtworzone w przestrzeni [29].

Podmiejski urok Wilanowa wygasa, stopniowo nabierając cech przedmieścia. Ważne by nowe otoczenie nie wpłynęło destrukcyjnie na „magię miejsca”, przenosząc środek ciężkości odbioru przestrzeni na zwartą zabudowę osiedla mieszkaniowego, czy będące w planach budowy przy ul. Przyczółkowej centrum handlowe Wilanów, przy których funkcji i skali zagubić się może ,genius loci” Wilanowa [30].

Językiem komunikacji architektury z odbiorcą jest forma, która powinna podejmować dialog z widzem, a kontekst historyczny jest wyzwaniem dla twórców i podnosi wartość nie tylko samej architektury ale i przestrzeni wokół niej. Złożoność odbioru placów i ulic daje możliwość bogatego ich kształtowania poprzez oferowanie również funkcji użyteczności publicznej: galerii sztuki, teatrów, domów muzyki, plastyki, ,zielonych” salonów na otwartym powietrzu, itp. wartości mogących zaspokajać potrzeby rekreacyjne, kulturalne czy edukacyjne, podkreślających rodowód miejsca [31], nie wywołując przy tym uczucia chaosu architektonicznego [32]. Przy czym rozwiązania formalne ciągów komunikacyjnych w miastach XIX i XX - wiecznych tak chętnie przywoływane ze względu na walory artystyczne ale i urbanistyczne, zwarte formy zabudowy pierzei, w nowoczesnej urbanistyce mogą posłużyć jako inspiracja do stworzenia pierzei współczesnej. Nowe ulice i place, w nawiązaniu do dawnej oprawy otrzymałyby zróżnicowaną bądź dopasowaną w formę, jednak utrzymaną w ramach ograniczających dowolność, bryły budynków właściwie wpisanych w kontekst, koniecznie dopasowane lub chociaż „uzgodnione ze sobą”.

\section{Zakończenie}

Czasy najnowsze to okres wzmożonej rozbudowy dzielnicy w formie zabudowy uzupełniającej na koronie skarpy warszawskiej Służewa i Ursynowa i Kabat, dzięki projektowanej południowej obwodnicy Warszawy i inwestycji osiedla Miasteczko Wilanów. Trudno nie oprzeć się wrażeniu, że wprowadzanie w ostatnich latach nowego ładu urbanistycznego w tym rejonie obarcza planistów i inwestorów oraz władze dzielnicy/miasta szczególnym zadaniem harmonijnego wplecenia nowej architektury, sieci dróg w ustalony wcześniej porządek przestrzenny. Zagospodarowania tej części miasta, będącej przez wieki zielonym krajobrazem utrwalonym na XVIII wiecznych wedutach Canaletta, z osiowymi arteriami, prowadzącymi do wysokiej klasy założeń pałacowo-ogrodowych jest zapewne koniecznością naszych czasów ale i trudnym wyzwaniem. Należy przy tym mieć na uwadze by architektura nowej przestrzeni publicznej była wyłaniana na drodze konkursów, ale i z uwzględnieniem głosu i oczekiwań społeczności lokalnej. 


\section{Literatura}

[1] Nietyksza M., Pruss W., Zmiany w układzie przestrzennym miasta. Integracja obszaru miasta w pierwszej połowie XIX wieku, oraz Stefaniak Z., Strefa podmiejska, inkorporacja 1916 r., w: Wielkomiejski rozwój Warszawy do 1918 r., pod. red. I. Pietrzak-Pawłowskiej, Warszawa 1973, s. 21, 40-43.

[2] Putkowska J. Architektura Warszawy XVII wieku, Warszawa 1991, s. 78-79, 87, 92, 108.

[3] Piber M. Stużew średniowieczny, Warszawa 2001, s. 35-41-42, 55-57, 66.

[4] Drozdowski M.M., Zahorski A. Historia Warszawy, Warszawa 1981, s. 15-19.

[5] Gieysztor Al. Ksztalty Warszawy, Biuletyn Historii Sztuki R.IX, 1947, z. 1-2, z. 162.

[6] Fijałkowski W. Wilanów, Warszawa 1973, s.6.

[7] Smoleńska B. Z dziejów dóbr wilanowskich w XVI-XVIII w., w: Rocznik Warszawski, XV, 1979, s. 290.

[8] Fijałkowski W. Królewski Wilanów, [bd., bm.], s. 108.

[9] Fijałkowski W. Królewskie założenia ogrodowe w południowej Warszawie, w: Królewskie ogro$d y$ w Polsce, pod red. M. Szafrańskiej, Warszawa 2001, s. 205, il. 1.

[10] Starzyński J. Wilanów, dzieje budowy pałacu za Jana III, Warszawa 1976, s. 87-108.

[11] Nowak J. Dobra wilanowskie za Elżbiety Sieniawskiej 1720-1729 w świetle archiwaliów Biblioteki Czartoryskich w Krakowie, w: Studia Wilanowskie, XIV, Warszawa 2003, s. 74, 80-81.

[12] Polski Słownik Biograficzny, Warszawa-Kraków, 1996, t. 37, s. 90-95, hasło: Sieniawska Elżbieta Helena z Lubomirskich.

[13] Putkowska J. Warszawski zespót rezydencjonalny Elżbiety i Adama Sieniawskich, praca statutowa, 1998, Wydział Architektury Politechniki Warszawskiej, s. 10.

[14] Putkowska J. Warszawskie rezydencje na przedmieściach i pod miastem w XVI - XVIII wieku, Warszawa 2016, s. 102.

[15] Fijałkowski W. Królewski Wilanów, [bd., bm], s. 122.

[16] Bohdziewicz P. Korespondencja artystyczna Elżbiety Sieniawskiej z lat 1700-1729 w Zbiorach Czartoryskich w Krakowie, Lublin, 1964, s. 74.

[17] Małcużyński W. Rozwój terytorialny miasta Warszawy, Warszawa 1900, s.155 oraz aneks nr 8.

[18] Kwiatkowski M. Kompozycja przestrzenna Łazienek Stanisławowskich, w: Królewskie ogrody w Polsce, pod. red. M. Szafrańskiej, Warszawa 2001, s. 320, 334-342.

[19] Fijałkowski W. Wilanów, Warszawa 1972, s. 18.

[20] Jaroszewski T.S. Księga Pałaców Warszawy, Warszawa 1985, s. 67.

[21] Stopka A., Okoński Z., Prokom Investments, Miasteczko Wilanów, prestiż i skala zobowiazuje, Urbanista 9 (2003) 17-18.

[22] Gzell S., Kurzątkowska A., Witkowska A., Zdunek-Wielgołaska J. Obszarowa granica miasta zwartego, Warszawa 2012, s. 11, 25, 37.

[23] Buczek G. Planować miasto tak, by chciało się w nim żyć..., Urbanista 1 (2006) 18.

[24] Jakość przestrzeni - interes miasta czy inwestora?, Urbanista 9 (2003) 21-22.

[25] Mostowska M. Public space lost. The ambiguity of the shared space, Urbanistyka 10 (2005) 94.

[26] Flecken U. What makes good Town centres? On policentrality in Berlin, Urbanistyka 10 (2005) 54-57.

[27] Krier L., Architektura wspólnoty, Gdańsk, 2011, s. 101, 119, 127.

[28] Solarek K., Współczesne koncepcje rozwoju miasta, Kwartalnik Architektury i Urbanistyki 4 (2011) $59,63$.

[29] Kłosek-Kozłowska D. Ochrona wartości kulturowych miast a urbanistyka, Warszawa 2007, s. 113.

[30] Jaskanis P., Gutowski B. Muzeum w przestrzeni społecznej, Fenomen Genius Loci-tożsamość miejsca w kontekście historycznym $i$ wspótczesnym. Materiały konferencji zorganizowanej przez Muzeum w Wilanowie, grudzień 2007, IHS UKSW w Warszawie, Warszawa 2009, s. 5-7.

[31] Maga-Jagielnicka R. Place miejskie - zjawiska kulturowe ksztattujące tożsamość przestrzeni, w: Fenomen Genius Loci-tożsamość miejsca w kontekście historycznym i współczesnym. Materiały 
konferencji zorganizowanej przez Muzeum w Wilanowie, grudzień 2007, IHS UKSW w Warszawie, Warszawa 2009, s. 28, 30, 32.

[32] Roguska J. Oprawa architektoniczna ulic warszawskich $w$ drugiej połowie XIX i na początku XX wieku jako wyraz ich funkcji i znaczenia w mieście, Kwartalnik Historii i Kultury Materialnej 3-4 (1998) 335-336.

\title{
Palace in Wilanow - the royal 'villa rustica' stands as a manor and a factor influencing development of one of the Warsaw's districts
}

\author{
Katarzyna Dankiewicz \\ Warsaw University of Technology,e-mail: kadan@wp.eu
}

\begin{abstract}
The baroque royal villa in Wilanow is in a distant from a master residence of John Sobieski the IIIrd (royal castle). In the fourth quarter of XVII century Wilanow villa was a luxurious summer house for the royalties as well as self-sufficient residence with its own manors and farms.

Starting in 1677 king Sobieski created the Wilanow complex composed of the villa and the nearby lands. Later on, his successors increased the area making a great manor which belonged only to royal family. Consistent expansion of the villa and belonging lands by different owners which had a various tastes, financial possibilities and knowledge for the period of more than 300 years resulted in very diverse surrounding. Villa and then a palace holders manage to add representative parks and gardens according to the best European examples which today are historical values of Wilanów district.

Majority of the Wilanów buildings have a cultural functions as museums and scientific institutions nowadays. Its historical architecture refers to the baroque, classicism and historicism styles. The past development of the palace area was based on the formerly marked communication routes and observation axes which are current till today.

New urbanization concept - Miasteczko Wilanow (The Wilanow City), has liven up the historical district of Wilanow. Since 2000 developers are targeting Wilanów as a place for modern housing and retail, creating a mini-city for the luxury craving Warsaw residents. The new outlook is in the contrast of the districts historical features.

Are the new and old structures are possible to be consistent, respecting the surroundings? The expected cooperation of historical and modern architecture and integration of different spaces will be able to observe after the completion of whole investment.
\end{abstract}

Keywords: baroque royal villa, palace, open landscape, observation axes, genius loci, new and old architecture. 